\title{
Temporins: An Approach of Potential Pharmaceutic Candidates
}

\author{
Stella Maris Romero, ${ }^{1, *}$ Alejandra Beatriz Cardillo, ${ }^{2,3,{ }^{*}}$ María Camila Martínez Ceron, ${ }^{2,3}$ \\ Silvia Andrea Camperi, ${ }^{2,3}$ and Silvana Laura Giudicessi ${ }^{2,3}$
}

\begin{abstract}
Antimicrobial peptides (AMPs), also known as host defense peptides, are small and mostly polycationic molecules that form part of the innate immune response. There are currently more than 3000 experimentally reported AMPs. Particularly in frogs, the temporin family has been discovered as potential AMPs. The aim of this work is to review the latest publications about this class of peptides, discuss their properties, and present an update of the last studies and new discoveries in the field. More than 130 temporins have been identified in this family. The most studied temporins are temporin A (TA), temporin B (TB), and temporin L (TL). These peptides showed antimicrobial activity against gram-negative, gram-positive bacteria and fungi. Since the discovery of temporins in 1996, several groups of researchers isolated different peptides from various species of frogs that were included as members of this family. Although antimicrobial activity of many temporins has not been analyzed yet, most of them showed antimicrobial and antifungal activities. A combination of nanotechnology and AMPs for temporins in different antimicrobial treatments could be a promising alternative for resistant pathogens. These studies demonstrate that, even with the advancement in scientific research on the composition and antimicrobial activity of temporins, further studies are necessary to wholly understand their components and mechanisms of action.
\end{abstract}

Keywords: antifungals; antimicrobial peptides; drug delivery; frog

\begin{abstract}
A NTIMICROBIAL PEPTIDES (AMPs), also known as host defense peptides (HDPs), are small and mostly polycationic molecules that form part of the innate immune response. Most of the AMPs share common features, such as small size, with cationic and hydrophobic sequences within a linear or cyclic structure. The AMPs can inhibit or eliminate bacteria at micromolar concentrations, often by non-specific mechanisms. Moreover, AMPs can kill antibiotic-resistant bacteria [1].

Currently, there are more than 3000 reported AMPs, including both natural peptides produced by living organisms from protozoa to animals and plants and artificial synthetic peptides. The vast number of compounds with known biologic activities are listed in specialized AMP databases such as the Antimicrobial Peptide Database 3 (APD3, [2]), the Collection of Anti-Microbial Peptides (CAMPR3, [3]) and the Database Linking Antimicrobial Peptides (LAMP, [4]). This list con-
\end{abstract}

tains 44 AMP families, including well- known AMPs such as defensins, brevinines, esculentins, japonicins, nigrocins, palustrins, ranacyclins, ranatuerins, cecropins, temporins, magainins, and dermaseptins, some of them studied recently [5].

Frogs (family Ranidae) synthesize a remarkably diverse range of antimicrobial peptides that are released from the granular glands to skin secretions in a very high concentration and a holocrine manner as a consequence of stress or tissue injury. These peptides serve to protect the frog against invasion by a variety of pathogenic micro-organisms and represent a component of the innate immunity of these organisms [6,7].

Within this arsenal of defensive peptides, some members of the temporin family were described [8]. These hydrophobic, C-terminally $\alpha$-amidated peptides were first identified in the skin of the Asian frog Rana erythraea and the European frog $R$. esculenta (reclassified as a hybrid between Pelophylax

\footnotetext{
${ }^{1}$ Instituto Multidisciplinario de Biología Vegetal (IMBIV), Córdoba, Argentina.

${ }^{2}$ Universidad de Buenos Aires, Facultad de Farmacia y Bioquímica, Cátedra de Biotecnología, Buenos Aires, Argentina.

${ }^{3}$ CONICET-Universidad de Buenos Aires, Instituto de Nanobiotecnología (NANOBIOTEC), Buenos Aires, Argentina.

*Both authors contributed equally to the article.
} 
ridibundus and $P$. lessonae) on the basis of their hemolytic activity [9]. In 1996, Simmaco et al. [10] identified these peptides in the skin of the European red frog $R$. temporaria. Later, they were also discovered in frogs of Northern America and Eurasian origin as well as in the venom of wasps [11,12].

Previous reports reviewed only 75 temporins. In addition, in the last five years, new members of this family were described in different frog species and studied for antimicrobial activity. Moreover, new approaches for pharmacologic discoveries, drug delivery, and nanotechnology have been applied using temporins because of their interesting properties and the well-known antimicrobial activity. In particular, two of the most studied temporins (temporin A and B) were used recently as potential candidates in medical and molecular new researches.

The aim of this work is to review the latest publications concerning this family of peptides, discuss their properties and potential applications, and provide an update of the last studies and new discoveries in the field.

\section{Temporins}

Initially, temporins were described as "Vespa-like" because of their structural similarity to the short (13-14 amino acids) peptides with chemotactic and histamine-releasing properties isolated from the venom of wasps of the genus Vespa [12]. Many peptides from the wasp venom have been used as antimicrobial drugs for many purposes - for example, intravascular stents infections [13], and other bacterial [14,15] or fungal [16]. Temporins present some similarities to these Vespa peptides-for example, low molecular masses, hydrophobic properties, and antimicrobial activity. The derived amino acid sequence for temporins is FLP(I/L)IASLL(S/G) KLL-NH $\mathrm{N}_{2}$, and the general amino acid type sequence is $\mathrm{X}_{1} \mathrm{X}_{2} \mathrm{X}_{3} \mathrm{X}_{4} \mathrm{X}_{5} \mathrm{X}_{6} \mathrm{Y}_{7} \mathrm{X}_{8} \mathrm{X}_{9} \mathrm{Y}_{10} \mathrm{Y}_{11}{ }^{+} \mathrm{X}_{12} \mathrm{X}_{13}-\mathrm{NH}_{2} \quad(\mathrm{X}=$ hydrophobic, $\mathrm{Y}=$ hydrophilic and $\mathrm{Y}^{+}=$charged amino acid).

Hydrophobic residues represent $70 \%$ of the peptide sequence, leucine being the most abundant amino acid. In addition, $\mathrm{X}_{2}, \mathrm{X}_{3}, \mathrm{X}_{9}$, and $\mathrm{X}_{13}$ are highly conserved amino acids [17]. Most of the temporins adopt an $\alpha$-helical conformation in hydrophobic environments [18].

More than 130 members of the temporin family have been identified in the skins of Eurasian, Asian, and North American ranids (Table 1, [19-66]). The temporins are among the most highly variable of all antimicrobial peptides. Most contain a single basic residue (generally Lys) giving a charge of +1 , but several temporins lack this structural feature. Temporin L, 1-CEa, 1-CEc, 1-CSd, CPa, 1Dra, 1DRb, HN1, 1Lb, 1Lc, LTb, LT2, 1Ola, PRc, PTa, Ra, RN3, and 1TGb contain two basic residues. In addition, 24 temporins have no charge and three (CDYa, CDYc, and $1 \mathrm{Ja}$ ) have acidic amino acids, with negative charge (Fig. 1). They are C-terminally $\alpha$-amidated, and their amino acid sequences are composed mainly by hydrophobic residues.

Temporins present interesting properties that make them good candidates for biologic investigation. Some of these properties are: (1) They are small amphipathic $\alpha$-helical AMPs (typically 13 amino acids); (2) they have low positive net charge at a neutral $\mathrm{pH}$ (between 0 and +3 ); (3) their short sequence provides low cost-efficient chemical synthesis; (4) some of the temporins act efficiently against a wide range of pathogens (bacteria, viruses, filamentous fungi, yeasts, and protozoa) and are not toxic to mammalian cells; (5) their mechanism of action is mainly based on cytoplasmic membrane perturbation, but in a different way from that proposed for the majority of cationic $\alpha$-helical AMPs; (6) some temporins display antimicrobial and chemotactic activities, immunomodulatory effects, and preserve biologic function in serum; (7) they display synergistic action when combined with conventional antibiotic agents; (8) they show in vivo efficacy as topical prophylactic agents against infections and in vivo anti-endotoxic effects $[67,68]$.

Although most temporins are inhibitors of gram-positive bacteria, some peptides from this family seem to be atypical in displaying activity against reference strains of several clinically relevant gram-negative species and against the opportunistic yeast pathogen Candida albicans (Fig 2).

The mode of action of the temporin is still uncertain, but some researchers found that the spatial conformation is essential to penetrate the cell membrane. In general, temporins adopt an $\alpha$-helix conformation, although this can change in different mediums [67,69-71].

\section{Temporins A, B, and $\mathrm{L}$}

Temporins A, B, and $\mathrm{L}$ are the most studied as antimicrobial peptides.

\section{Temporin A}

Structure-activity studies with temporin A (TA, FLPLIGRVLSGIL-NH $\mathrm{N}_{2}$ ) indicated that a hydrophobic Nterminal residue and bulky hydrophobic residues at positions 5 and 12 are important determinants of antibacterial activity [68]. The TA is preferentially active against gram-positive bacteria and has a moderate hemolytic activity [72]. The TA, together with temporin $\mathrm{L}$, is one of the most studied peptides, and it was found to show interesting antimicrobial activity.

For example, together with temporin $1 \mathrm{P}$ from $R$. pipiens and a wasp temporin, TA successfully inhibited the growth of the fungus Batrachochytrium dendrobatidis, a pathogen associated with global amphibian declines. In this case, the results obtained with the peptides indicated that the ability to penetrate membranes and form an $\alpha$-helical structure was important for their effectiveness against the pathogen [73]. Also, this peptide showed antimicrobial activity against Staphylococcus aureus, Enterococcus faecium, and E. faecalis $[74,75]$.

Wade et al. [76] synthetized a hybrid peptide (CA(1-7)TA(2-9) $\mathrm{NH}_{2}$ (CATA)), containing portions of the amino-acid sequences of TA and cecropin A (CA) and evaluated its hemolytic, anticoagulant, and antifungal properties. Cecropin A is a gene encoded antibiotic peptide that was originally isolated from the silkmoth Hyalophora cecropia larval hemolymph. In previous works, portions of amino acids of CA were combined with melittin, a peptide whose sequence of the amino terminal portion is similar to TA. They found that both TA and CATA are not hemolytic at concentrations at which TA yields antimicrobial effects (less than $12 \mu \mathrm{M}$ ). The CATA has a weaker but still significant activity against the chytrid fungus Batrachochytrium dendrobatidis. While TA does not affect coagulation times at the concentrations studied, CATA inhibits coagulation at all concentrations tested [76].

In another study, TA structure was modified to make three different analogues: A monomeric carboxy peptide (TAc), a dimeric temporin (TAd), and a synthesized analogue using a 
Table 1. Updated List of Temporins Described since First Discovery in 1996

\begin{tabular}{|c|c|c|c|c|c|c|c|}
\hline Temporin & Amino acid sequence & $\begin{array}{c}\text { No. } \\
\text { amino } \\
\text { acids }\end{array}$ & Frog specie & Charge & $\begin{array}{c}\text { Basic } \\
\text { amino } \\
\text { acids }\end{array}$ & $\begin{array}{c}\text { Acidic } \\
\text { amino } \\
\text { acids }\end{array}$ & Reference \\
\hline A & FLPLIGRVLSGIL-NH ${ }_{2}$ & 13 & Rana temporaria & +1 & 1 & 0 & {$[10]$} \\
\hline B & LLPIVGNLLKSLL-NH $_{2}$ & 13 & Rana temporaria & +1 & 1 & 0 & [10] \\
\hline $\mathrm{C}$ & LLPILGNLLNGLL-NH $_{2}$ & 13 & Rana temporaria & 0 & 0 & 0 & [10] \\
\hline $\mathrm{D}$ & LLPIVGNLLNSLL-NH $_{2}$ & 13 & Rana temporaria & 0 & 0 & 0 & {$[10]$} \\
\hline $\mathrm{E}$ & VLPIIGNLLNSLL-NH 2 & 13 & Rana temporaria & 0 & 0 & 0 & {$[10]$} \\
\hline $\mathrm{F}$ & FLPLIGKVLSGIL-NH 2 & 13 & Rana temporaria & +1 & 1 & 0 & [10] \\
\hline $\mathrm{G}$ & FFPVIGRILNGIL-NH 2 & 13 & Rana temporaria & +1 & 1 & 0 & {$[10]$} \\
\hline $\mathrm{H}$ & LSPNLLKSLL-NH $_{2}$ & 10 & Rana temporaria & +1 & 1 & 0 & {$[10]$} \\
\hline $\mathrm{K}$ & LLPNLLKSLL-NH $_{2}$ & 10 & Rana temporaria & +1 & 1 & 0 & {$[10]$} \\
\hline $\mathrm{L}$ & FVQWFSKFLGRIL-NH ${ }_{2}$ & 13 & Rana temporaria & +2 & 2 & 0 & {$[10]$} \\
\hline $1 \mathrm{ARa}$ & FLPIVGRLISGLL-NH ${ }_{2}$ & 13 & Rana areolata & +1 & 1 & 0 & [19] \\
\hline 1AUa & PLPIIGQLLSGLL-NH & 13 & Rana aurora aurora & 0 & 0 & 0 & [20] \\
\hline ALa & FLPIVGKLLSGLSGLL-NH ${ }_{2}$ & 16 & Amolops loloensis & +1 & 1 & 0 & [21] \\
\hline Alb & FLPIVGKLLSGLL-NH ${ }_{2}$ & 13 & Amolops loloensis & +1 & 1 & 0 & [22] \\
\hline ALc & LLPIVGKGLSGKL-NH ${ }_{2}$ & 13 & Amolops loloensis & +2 & 2 & 0 & [22] \\
\hline ALd & FLPIAGKLLSGLSGLL-NH & 16 & Amolops loloensis & +1 & 1 & 0 & {$[22]$} \\
\hline ALe & FFPIVGKLLFGLSGLL-NH & 16 & Amolops loloensis & +1 & 1 & 0 & {$[22]$} \\
\hline ALf & FFPIVGKLLSGLSGLL-NH 2 & 16 & Amolops loloensis & +1 & 1 & 0 & [22] \\
\hline ALg & FFPIVGKLLFGLFGLL & 16 & Amolops loloensis & +1 & 1 & 0 & [22] \\
\hline ALh & FLPIVGKLLSGLSGLS-NH & 16 & Amolops loloensis & +1 & 1 & 0 & {$[22]$} \\
\hline ALi & FFPIVGKLLSGLL-NH & 13 & Amolops loloensis & +1 & 1 & 0 & {$[22]$} \\
\hline $\mathrm{ALj}$ & FFPIVGKLLFGLL-NH ${ }_{2}$ & 13 & Amolops loloensis & +1 & 1 & 0 & [22] \\
\hline ALk & FFPIVGKLLS-NH ${ }_{2}$ & 10 & Amolops loloensis & +1 & 1 & 0 & [22] \\
\hline $1 \mathrm{BYa}$ & FLPIIAKVLSGLL-NH ${ }_{2}$ & 13 & Rana boylii & +1 & 1 & 0 & [23] \\
\hline $1 \mathrm{Ca}$ & FLPFLAKILTGVL-NH $_{2}$ & 13 & Rana clamitans & +1 & 1 & 0 & [24] \\
\hline $1 \mathrm{Cb}$ & FLPLFASLIGKLL-NH $_{2}$ & 13 & Rana clamitans & +1 & 1 & 0 & [24] \\
\hline $1 \mathrm{Cc}$ & FLPFLASLLTKVL-NH ${ }_{2}$ & 13 & Rana clamitans & +1 & 1 & 0 & [24] \\
\hline $1 \mathrm{Cd}$ & FLPFLASLLSKVL-NH & 13 & Rana clamitans & +1 & 1 & 0 & [24] \\
\hline $1 \mathrm{Ce}$ & FLPFLATLLSKVL-NH & 13 & Rana clamitans & +1 & 1 & 0 & [24] \\
\hline $1 \mathrm{CEa}$ & FVDLKKIANIINSIF-NH $_{2}$ & 15 & Rana chensinensis & +1 & 1 & 0 & {$[25]$} \\
\hline $1 \mathrm{CEb}$ & ILPILSLIGGLLGK-NH $_{2}$ & 14 & Rana chensinensis & +1 & 1 & 0 & [25] \\
\hline $1 \mathrm{CEc}$ & IIPLPLGYFAKKT-NH 2 & 13 & Rana chensinensis & +2 & 2 & 0 & {$[25]$} \\
\hline CDYa & VLPLVGNLLNDLL-NH & 13 & Rana dybowskii & -1 & 0 & 1 & {$[26]$} \\
\hline $\mathrm{CDYb}$ & ILPILAPLIGGLL-NH $_{2}$ & 13 & Rana dybowskii & 0 & 0 & 0 & [26] \\
\hline CDYc & VLPLVGNLLNDLL-NH ${ }_{2}$ & 13 & Rana dybowskii & -1 & 0 & 1 & [26] \\
\hline CDYd & FIGPLISALASLFKG-NH & 15 & Rana dybowskii & +1 & 1 & 0 & {$[27 a]$} \\
\hline CDYe & FIGPIISALASLFGG-NH $_{2}$ & 15 & Rana dybowskii & 0 & 0 & 0 & {$[27 \mathrm{~b}]$} \\
\hline CG1 & FLPFVGNLLKGLL-NH ${ }_{2}$ & 13 & Amolops chunganensis & +1 & 1 & 0 & [28] \\
\hline $\mathrm{CG} 2$ & FFPIVGKLLSGLF-NH ${ }_{2}$ & 13 & Amolops chunganensis & +1 & 1 & 0 & {$[28]$} \\
\hline CG3 & FLPIVGKLLSGLF-NH & 13 & Amolops chunganensis & +1 & 1 & 0 & {$[28]$} \\
\hline CG4 & FLPILGNLLNGLL-NH & 13 & Amolops chunganensis & 0 & 0 & 0 & {$[28]$} \\
\hline CG5 & FLPFVGNLLNGLL-NH ${ }_{2}$ & 13 & Amolops chunganensis & 0 & 0 & 0 & {$[28]$} \\
\hline $1 \mathrm{CSa}$ & FLPIVGKLLSGLL-NH ${ }_{2}$ & 13 & Rana cascadae & +1 & 1 & 0 & [29] \\
\hline $1 \mathrm{CSb}$ & FLPIIGKLLSGLL-NH 2 & 13 & Rana cascadae & +1 & 1 & 0 & [29] \\
\hline $1 \mathrm{CSc}$ & FLPLVTGLLSGLL-NḦ$_{2}$ & 13 & Rana cascadae & 0 & 0 & 0 & [29] \\
\hline $1 \mathrm{CSd}$ & NFLGTLVNLAKKIL-NH $_{2}$ & 14 & Rana cascadae & +2 & 2 & 0 & [29] \\
\hline $\mathrm{CPa}$ & IPPFIKKVLTTVF-NH 2 & 13 & Lithobates capito & +2 & 2 & 0 & [30] \\
\hline $\mathrm{CPb}$ & FLPIVGRLISGIL-NH ${ }_{2}$ & 13 & Lithobates capito & 0 & 0 & 0 & [30] \\
\hline 1DRa & HFLGTLVNLAKKIL-NH & 14 & Rana aurora draytonii & +2 & 2 & 0 & [31] \\
\hline $1 \mathrm{DRb}$ & NFLGTLVNLAKKIL-NH & 14 & Rana aurora draytonii & +2 & 2 & 0 & [31] \\
\hline 1DRc & FLPIIASVLSSLL-NH ${ }_{2}$ & 13 & Rana aurora draytonii & 0 & 0 & 0 & [31] \\
\hline $1 \mathrm{DYa}$ & FIGPIISALASLFG- $\mathrm{NH}_{2}$ & 14 & Rana dybowskii & 0 & 0 & 0 & [32] \\
\hline $1 \mathrm{Ec}$ & FLPIIAGLLSKLF-NH ${ }_{2}$ & 13 & Rana esculenta & +1 & 1 & 0 & [33] \\
\hline $1 \mathrm{Ee}$ & FLPVIAGVLSKLF-NH & 13 & Pelophylax kl. esculentus & +1 & 1 & 0 & [34] \\
\hline $1 \mathrm{Ga}$ & SILPTIVSFLSKVF-NH & 14 & Rana grylio & +1 & 1 & 0 & [35] \\
\hline $1 \mathrm{~Gb}$ & SILPTIVSFLSKFL-NH $_{2}$ & 14 & Rana grylio & +1 & 1 & 0 & [35] \\
\hline $1 \mathrm{Gc}$ & SILPTIVSFLTKFL-NH ${ }_{2}$ & 14 & Rana grylio & +1 & 1 & 0 & {$[35]$} \\
\hline $1 \mathrm{Gd}$ & FILPLIASFLSKFL-NH ${ }_{2}$ & 14 & Rana grylio & +1 & 1 & 0 & {$[35]$} \\
\hline $\mathrm{GH}$ & FLPLLFGAISHLL-NH $_{2}^{2}$ & 13 & Hylarana guentheri & 0 & 0 & 0 & [36] \\
\hline Gua & FLQHIIGALSHIF-NH ${ }_{2}$ & 13 & Hylarana guntheri & 0 & 0 & 0 & [37] \\
\hline Gub & FLPLLFGAISHIL-NH & 13 & Hylarana guntheri & +1 & 1 & 0 & [37] \\
\hline Guc & FFPLIFGALSSILPKIL-NH & 17 & Hylarana guntheri & +1 & 1 & 0 & [37] \\
\hline $1 \mathrm{HK}$ & SIFPAIVSFLSKFL-NH ${ }_{2}$ & 14 & Rana heckscheri & +1 & 1 & 0 & [38] \\
\hline
\end{tabular}


TABle 1. (Continued)

\begin{tabular}{|c|c|c|c|c|c|c|c|}
\hline Temporin & Amino acid sequence & $\begin{array}{c}\text { No. } \\
\text { amino } \\
\text { acids }\end{array}$ & Frog specie & Charge & $\begin{array}{c}\text { Basic } \\
\text { amino } \\
\text { acids }\end{array}$ & $\begin{array}{c}\text { Acidic } \\
\text { amino } \\
\text { acids }\end{array}$ & Reference \\
\hline HN1 & AILTTLANWARKFL-NH ${ }_{2}$ & 14 & Odorrana hainanensis & +2 & 2 & 0 & [39] \\
\hline HN2 & NILNTIINLAKKIL-NH 2 & 14 & Odorrana hainanensis & +2 & 2 & 0 & [39] \\
\hline $1 \mathrm{Ja}$ & ILPLVGNLLNDLL-NH ${ }_{2}$ & 13 & Rana japonica & -1 & 0 & 1 & [40] \\
\hline $1 \mathrm{La}$ & VLPLISMALGKLL-NH & 13 & Rana luteiventris & +1 & 1 & 0 & [41] \\
\hline $1 \mathrm{Lb}$ & NFLGTLINLAKKIM-NḦ ${ }_{2}$ & 14 & Rana luteiventris & +2 & 2 & 0 & [41] \\
\hline $1 \mathrm{Lc}$ & FLPILINLIHKGLL-NH ${ }_{2}$ & 14 & Rana luteiventris & +2 & 2 & 0 & [41] \\
\hline LK1 & FFPLLFGALSSMMPKLF-NH ${ }_{2}$ & 17 & Limnonectes kuhlii & +1 & 1 & 0 & [42] \\
\hline LTa & FFPLVLGALGSILPKIF-NH & 17 & Hylarana latouchii & +1 & 1 & 0 & [43] \\
\hline $\mathrm{LTb}$ & FIITGLVRGLTKLF-NH 2 & 14 & Hylarana latouchii & +2 & 2 & 0 & [43] \\
\hline LTc & SLSRFLSFLKIVYPPAF-NH ${ }_{2}$ & 17 & Hylarana latouchii & +2 & 2 & 0 & [43] \\
\hline $\mathrm{LTe}$ & FLAGLIGGLAKML-NH ${ }_{2}$ & 13 & Hylarana latouchii & +1 & 1 & 0 & [44] \\
\hline LT1 & FLPGLIAGIAKML-NH ${ }_{2}{ }^{2}$ & 13 & Hylarana latouchii & +1 & 1 & 0 & {$[45]$} \\
\hline LT2 & FLPIALKALGSIFPKIL-NH ${ }_{2}$ & 17 & Hylarana latouchii & +2 & 2 & 0 & {$[45]$} \\
\hline $1 \mathrm{M}$ & FLPIVGKLLSGLL-NH ${ }_{2}$ & 13 & Rana muscosa & +1 & 1 & 0 & [46] \\
\hline $10 \mathrm{a}$ & FLPLLASLFSRLL-NH $_{2}$ & 13 & Rana ornativentris & +1 & 1 & 0 & [47] \\
\hline $1 \mathrm{Ob}$ & FLPLIGKILGTIL-NH ${ }_{2}$ & 13 & Rana ornativentris & +1 & 1 & 0 & [47] \\
\hline $10 \mathrm{c}$ & FLPLLASLFSRLF-NH $_{2}$ & 13 & Rana ornativentris & +1 & 1 & 0 & [47] \\
\hline $10 d$ & FLPLLASLFSGLF-NH ${ }_{2}$ & 13 & Rana ornativentris & 0 & 0 & 0 & [47] \\
\hline $10 \mathrm{e}$ & ILPLLGNLLNGLL-NH $_{2}$ & 13 & Rana ornativentris & 0 & 0 & 0 & [48] \\
\hline $10 f$ & SLLLKGLASIAKLF-NH $_{2}$ & 14 & Rana ornativentris & +1 & 1 & 0 & [48] \\
\hline $10 g$ & FLSSLLSKVVSLFT-NH ${ }_{2}$ & 14 & Rana ornativentris & +1 & 1 & 0 & [48] \\
\hline $10 \mathrm{La}$ & FLPFLKSILGKIL-NH ${ }_{2}$ & 13 & Rana okaloosae & +2 & 2 & 0 & [49] \\
\hline $1 \mathrm{OLb}$ & FLPFFASLLGKLL-NH $_{2}$ & 13 & Rana okaloosae & +1 & 1 & 0 & [49] \\
\hline $1 \mathrm{P}$ & FLPIVGKLLSGLL-NH 2 & 13 & Rana pipiens & +1 & 1 & 0 & [41] \\
\hline 1PLa & FLPLVGKILSGLI-NH ${ }_{2}$ & 13 & Rana palustris & +1 & 1 & 0 & {$[50]$} \\
\hline 1PRa & ILPILGNLLNGLL-NH $_{2}$ & 13 & Rana pirica & 0 & 0 & 0 & [51] \\
\hline $1 \mathrm{PRb}$ & ILPILGNLLNSLL-NH $_{2}$ & 13 & Rana pirica & 0 & 0 & 0 & [51] \\
\hline $\mathrm{PRa}$ & FLPILGNLLSGLL-NH $_{2}$ & 13 & Rana pretiosa & 0 & 0 & 0 & [52] \\
\hline $\mathrm{PRb}$ & FLPIITNLLGKLL-NH ${ }_{2}$ & 13 & Rana pretiosa & +1 & 1 & 0 & [52] \\
\hline PRc & $\mathrm{NFLDTLINLAKKFI-NH}_{2}$ & 14 & Rana pretiosa & +1 & 1 & 1 & [52] \\
\hline PTa & FFGSVLKLIPKIL-NH ${ }_{2}$ & 13 & Hylarana picturata & +2 & 2 & 0 & [53] \\
\hline $\mathrm{Ra}$ & FLKPLFNAALKLLP-NH $_{2}$ & 14 & Rana ridibunda & +2 & 2 & 0 & {$[54]$} \\
\hline $\mathrm{Rb}$ & FLPVLAGVLSRA-NH ${ }_{2}$ & 12 & Rana ridibunda & +1 & 1 & 0 & [54] \\
\hline $1 \mathrm{Re}$ & FLPGLLAGLL-NH $_{2}$ & 10 & Pelophylax kl. esculentus & 0 & 0 & 0 & [34] \\
\hline RN1 & FLPLVLGALSGILPKIL-NH ${ }_{2}$ & 17 & Rana nigrovittata & +1 & 1 & 0 & {$[55]$} \\
\hline RN2 & FFPLLFGALSSLLPKLF-NH ${ }_{2}$ & 17 & Rana nigrovittata & +1 & 1 & 0 & {$[55]$} \\
\hline RN3 & FFPLLFGALSSHLPKLF-NH ${ }_{2}$ & 17 & Rana nigrovittata & +2 & 2 & 0 & {$[55]$} \\
\hline $1 \mathrm{Sa}$ & FLSGIVGMLGKLF-NH 2 & 13 & Pelophylax saharica & +1 & 1 & 0 & [56] \\
\hline $1 \mathrm{Sb}$ & FLPIVTNLLSGLI-NH ${ }_{2}$ & 13 & Pelophylax saharica & 0 & 0 & 0 & [56] \\
\hline $1 \mathrm{Sc}$ & FLSHIAGFLSNLF-NH $_{2}$ & 13 & Pelophylax saharica & +1 & 1 & 0 & [56] \\
\hline $1 \mathrm{SKa}$ & FLPVILPVIGKLLNGIL-NH ${ }_{2}$ & 17 & Rana sakuraii & +1 & 1 & 0 & {$[57]$} \\
\hline $1 \mathrm{SKb}$ & FLPVILPVIGKLLSGIL-NH & 17 & Rana sakuraii & +1 & 1 & 0 & [57] \\
\hline $1 \mathrm{SPa}$ & FLSAITSILGKFF-NH & 13 & Rana septentrionalis & +1 & 1 & 0 & [58] \\
\hline $1 \mathrm{SPb}$ & FLSAITSLLGKLL-NH $_{2}$ & 13 & Rana septentrionalis & +1 & 1 & 0 & {$[58]$} \\
\hline $1 \mathrm{SPc}$ & FLSAITSILGKLF-NH $_{2}$ & 13 & Rana septentrionalis & +1 & 1 & 0 & {$[58]$} \\
\hline $\mathrm{SHa}$ & FLSGIVGMLGKLF-NH & 13 & Pelophylax saharica. & +1 & 1 & 0 & {$[59]$} \\
\hline $\mathrm{SHb}$ & FLPIVTNLSGLL-NH ${ }_{2}$ & 12 & Pelophylax saharica. & 0 & 0 & 0 & {$[59]$} \\
\hline SHc & FLSHIAGFLSNLF-NH 2 & 13 & Pelophylax saharica & +1 & 1 & 0 & {$[59]$} \\
\hline SHd & FLPAALAGIGGILGKLF-NH ${ }_{2}$ & 17 & Pelophylax saharica & +1 & 1 & 0 & [60] \\
\hline SHf & FFFLSRIF-NH 2 & 8 & Pelophylax saharica & +1 & 1 & 0 & [23] \\
\hline SN1 & FFPFLLGALGSLLPKIF-NH ${ }_{2}$ & 17 & Hylarana spinulosa & +1 & 1 & 0 & {$[61]$} \\
\hline SN2 & FITGLIGGLMKAL-NH ${ }_{2}$ & 13 & Hylarana spinulosa & +1 & 1 & 0 & [61] \\
\hline SN3 & FISGLIGGLMKAL-NH $_{2}$ & 13 & Hylarana spinulosa & +1 & 1 & 0 & [61] \\
\hline SN4 & FITGLISGLMKAL-NH $_{2}$ & 13 & Hylarana spinulosa & +1 & 1 & 0 & [61] \\
\hline SN5 & FFPLVLGALGSILPKIF-NH & 17 & Hylarana spinulosa & +1 & 1 & 0 & [61] \\
\hline $1 \mathrm{TGa}$ & FLPILGKLLSGIL-NH & 13 & Rana tagoi & +1 & 1 & 0 & {$[62]$} \\
\hline $1 \mathrm{TGb}$ & AVDLAKIANKVLSSLF-NH ${ }_{2}$ & 16 & Rana tagoi & +1 & 2 & 1 & {$[63]$} \\
\hline $1 \mathrm{TGc}$ & FLPVILPVIGKLLSGIL-NH ${ }_{2}$ & 17 & Rana tagoi & +1 & 1 & 0 & [63] \\
\hline $1 \mathrm{TSa}$ & FLGALAKIISGIF-NH ${ }_{2}$ & 13 & Rana tsushimensis & +1 & 1 & 0 & {$[64]$} \\
\hline $1 \mathrm{TSb}$ & FLPLLGNLLNGLL-NH ${ }_{2}$ & 13 & Rana tsushimensis & 0 & 0 & 0 & [64] \\
\hline $1 \mathrm{TSc}$ & FLPLLGNLLRGLL-NH & 13 & Rana tsushimensis & +1 & 1 & 0 & [64] \\
\hline $1 \mathrm{TSd}$ & FLPLLASLIGGML-NH $_{2}$ & 13 & Rana tsushimensis & 0 & 0 & 0 & [64] \\
\hline $1 \mathrm{VE}$ & FLPLVGKILSGLI-NH ${ }_{2}$ & 13 & Rana (Odorrana) versabilis & +1 & 1 & 0 & {$[65]$} \\
\hline
\end{tabular}


TABle 1. (CONTINUed)

\begin{tabular}{|c|c|c|c|c|c|c|c|}
\hline Temporin & Amino acid sequence & $\begin{array}{c}\text { No. } \\
\text { amino } \\
\text { acids }\end{array}$ & Frog specie & Charge & $\begin{array}{c}\text { Basic } \\
\text { amino } \\
\text { acids }\end{array}$ & $\begin{array}{c}\text { Acidic } \\
\text { amino } \\
\text { acids }\end{array}$ & Reference \\
\hline $1 \mathrm{Va}$ & FLSSIGKILGNLL-NH $_{2}$ & 13 & Rana virgatipes & +1 & 1 & 0 & [66] \\
\hline $1 \mathrm{Vb}$ & FLSIIAKVLGSLF-NH ${ }_{2}$ & 13 & Rana virgatipes & +1 & 1 & 0 & [66] \\
\hline $1 \mathrm{Vc}$ & FLPLVTMLLGKLF-NH ${ }_{2}$ & 13 & Rana virgatipes & +1 & 1 & 0 & [66] \\
\hline Wa & FISKIASLGAGVLX-NH & 14 & Lithobates warszewitschii & +1 & 1 & 0 & [30] \\
\hline
\end{tabular}

The table shows the sequence, number of amino acids, positive, negative, and net charge of each temporin. Those amino acids in red $(\mathrm{K}, \mathrm{H}$, and $\mathrm{R})$ correspond to basic amino acids, and those in green (D, E) correspond to acidic amino acids.

new branching unit 3-N,N-di(3-aminopropyl)amino propanoic acid (DAPPA), which allows building of the parallelly symmetric $\alpha$-helical structures. These analogues were tested against S. aureus (gram-positive) and Escherichia coli (gram-negative). Both TA and TAd completely inhibited the growth of $S$. aureus, whereas TAc did not show any inhibitory activity. The TAd displayed antibacterial effect against E. coli, whereas monomeric TA did not show any activity at concentration higher than $20 \mathrm{mM}$. The results indicated that these structural modifications improved the antibacterial properties of TA especially because of the increase of the net charge of the peptide from +2 to +4 [77].

The TA enantiomer (with D-amino acids, D-TA) also showed good antimicrobial activity against bacteria, and the replacement of some amino acids improved the activity [68]. In another study, the D-TA and the reverse TA sequence (Rev-TA) were compared with TA. The TA induced monocyte migration, while both TA analogues did not, suggesting that TA-induced monocyte migration is based on a chiral interaction [78].

Other studies performed with temporin A, B, D, and $\mathrm{H}$ have shown that in Lysogeny broth (LB) medium, temporins $\mathrm{D}$ and $\mathrm{H}$ were completely inactive, whereas TA and TB showed a higher activity against the gram-positive bacterial strain than against the gram-negative one. In addition, TA and TB also caused total reduction in colony-forming units of $S$. aureus [67].

In addition, Magnoni et al. [79] found an anti-Leishmania activity at micromolar concentrations for $\mathrm{TA}$ and $\mathrm{TB}$ with no cytolytic activity against human erythrocytes. The ability of temporins to kill Leishmania amastigotes was assayed by inhi-

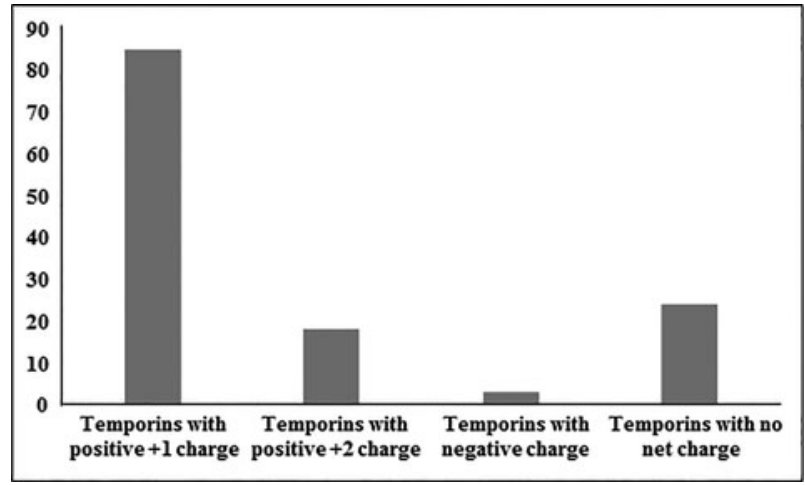

FIG. 1. Number of temporins with $+1,+2,-1$, and 0 charge. Most of the temporins (85 peptides) present +1 charge, 24 temporins have no net charge, 18 have +2 , and only three temporins have negative charge. bition of 3-(4,5-dimethylthiazol-2-yl)-2,5-diphenyltetrazolium bromide (MTT) reduction test [79]. Both temporins preserved their activity against the mammalian intracellular form of the parasite.

They also investigated whether the mode of action of temporins against Leishmania amastigotes was similar to that found for promastigotes. They found that TA and TB could induce the permeation of the amastigote membrane, although TB was more active than TA. In addition, both temporins induced the permeation of the membrane of amastigotes similarly to the promastigotes [67]. Finally, experiments with TA found that this peptide not only is suitable as an antimicrobial peptide but also can be administrated topically in mice wounds together with antibiotic agents, generating a significant bacterial growth inhibition and acceleration of wound repair process [80].

To improve AMPs administration, new polymeric carriers can be used as highly controlled release devices. Piotrowska et al. [81] chose the peptides citropin 1.1 (CIT) and TA for their experiments. They found that the release rate of the active pharmaceutic ingredients (APIs) was strongly dependent on the API characteristics and the matrix microstructure. They investigated the effect of the carrier polymer microstructure in both peptide kinetics release in vitro. Results suggested these polymeric devices as good therapeutic carrier candidates and TA as a prospective therapeutic option [81].

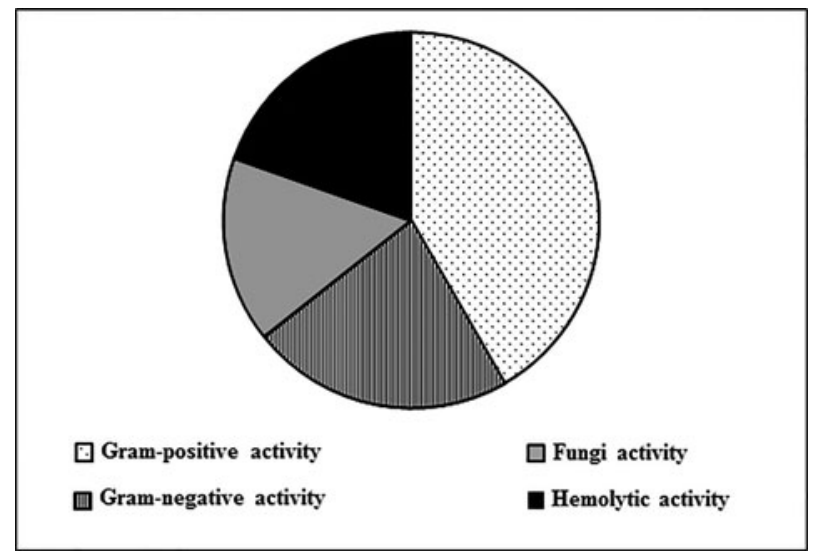

FIG. 2. Antimicrobial and hemolytic activity of the temporins. From 85 temporins analyzed against gram-positive bacteria, 83 showed positive activity; from 79 temporins analyzed against gram-negative bacteria, 45 showed positive activity; and 32 of 65 temporins showed good antimicrobial activity against fungi. From 57 temporins, 39 presented hemolytic activity. 
The TA applications were not limited to antimicrobial activities. Musale et al. [82] found that TA, together with temporin $\mathrm{F}(\mathrm{TF})$ and $\mathrm{G}$ (TG), produced concentrationdependent stimulation of insulin release from BRIN-BD11 rat clonal $\beta$-cells at concentrations $\geq 1 \mathrm{nM}$, without cytotoxicity at concentrations up to $3 \mathrm{mcM}$. In these experiments, TA was the most effective. Also, TA together with TF protected BRIN-BD11 cells against cytokine-induced apoptosis [82].

\section{Temporin B}

Malgieri et al. [83] elucidated mechanisms of action of temporin B (TB, LLPIVGNLLKSLL- $\mathrm{NH}_{2}$ ) synthetic derivatives. Some of these peptide derivatives showed gramnegative and gram-positive inhibition with no hemolytic activity. Marcocci et al. [84] recently demonstrated for the first time the in vitro anti-herpes simplex virus type 1 (HSV-1) activity of TB. A significant antiviral activity was observed in a pre-incubation of $\mathrm{HSV}-1$ with $20 \mathrm{mcg} / \mathrm{mL}$ of TB. When TB was added to HSV-1-infected cells, viral titer was significantly reduced. Moreover, the highest inhibition was obtained by pre-incubation of HSV-1 with the peptide for $1 \mathrm{~h}$ at $37^{\circ} \mathrm{C}$, demonstrating its viricidal activity [84].

In addiion, a $\mathrm{D}$ form of TB has been used together with TB to test the antimicrobial activity compared with CAMEL peptide $\left(\mathrm{CA}(1-7) \mathrm{M}(2-9) \mathrm{NH}_{2}\right)$. This last peptide is a 15residue hybrid amide peptide with seven amino acids that are derived from the sequence of cecropin A (silkmoth Hyalophora cecropia larvae) and eight amino acids from the sequence of melittin (honey-bee venom). The results showed that the antimicrobial activity of the $\mathrm{D}$ form of temporin $\mathrm{B}$ was detected after $30 \mathrm{~min}$, and no activity was detected after 24,48 , and $72 \mathrm{~h}$. The $\mathrm{D}$ isomer of temporin $\mathrm{B}$ was inactivated more slowly in feces than the $\mathrm{L}$ isomer [85].

Another study evaluated the role of each amino acid on the peptide activity of TB. Avitable et al. [86] performed a complete Ala scanning of TB by substituting one or two amino acids with alanine residues to obtain a series of TB analogues. Best results were obtained with the analogue TB_KKG6A (KKLLPIVANLLKSLLNH $\mathrm{N}_{2}$ ) that showed antimicrobial activity against gram-positive and gram-negative bacteria at a concentration of $5 \mathrm{mcM}$ [86]. This peptide, together with other analogues, was used to find antimicrobial activity against Pseudomonas aeruginosa. One of the TB analogues, TBKKG6A, exhibited strong antimicrobial activity [87].

In addition, enhancing the hydrophobicity of the $\mathrm{N}$-terminus and the cationicity of the $\mathrm{C}$-terminus in $\mathrm{TB}$ improves its membrane activity and potency against both gram-negative and gram-positive bacteria. In contrast, enhancing the cationicity of the N-terminus abrogates its ability to trigger channel conductance and renders it ineffective against $S$. aureus while nevertheless enhancing its potency against $E$. coli $[70]$.

In other studies concerning infection of human keratinocytes with $S$. aureus, TB and TA were used to improve the treatment against this bacterium. Results showed that TB killed ATCC-derived (ATCC: American Type Culture Collection) and multi-drug-resistant clinical isolates of S. aureus within infected human keratinocytes at a non-toxic concentration of $16 \mathrm{mcM}$ within $2 \mathrm{~h}$ and without injuring the host cells, whereas a weaker effect was displayed by TA. With the combination of antibacterial and wound-healing activities, TA and TB seemed to act as multi-functional mediators of innate immunity in humans [88]. In addition, TB acted synergistically with other reagents, such as cysteine and ethylenediaminetetraacetic acid. These combinations improved the antimicrobial activity of the temporin against $S$. epidermidis biofilms [89].

Lipopolysaccharides (LPS) have been important in temporin studies because of the interaction between them and the fact that LPS are the major structural component of the outer membrane of gram-negative bacteria. The LPS usually are used as models for molecular dynamics to study the antimicrobial activity of the temporins-for example, TB [90]. Also, LPS have been used in different studies using temporin L (see below).

These results make TB a promising alternative as an antibacterial drug, although its toxicity still needs more research, especially in mammalian cells. It is well known that AMPs represent promising therapeutic agents against bacterial and fungal pathogens, although one of their principal limitations is their cytotoxicity to eukaryotic cells and erythrocytes [91,92]. The TB is not an exception. Some alternatives to solve this problem have been proposed to improve its pharmaceutic development, such as TB encapsulation into chitosan nanoparticles [93].

\section{Temporin $L$}

Temporin L (TL, FVQWFSKFLGRIL- $\mathrm{NH}_{2}$ ) has a large antimicrobial activity, especially for fungal pathogens and gram-negative bacteria, while temporins are generally gram-positive inhibitors. This temporin has potential antiendotoxin properties and can strongly bind to purified $E$. coli LPS and interfere with its biologic activities in two rat models of gram-negative septic shock, protecting the animals against lethal endotoxemia [72].

The mechanism of action of TL (together with TB) to penetrate the phospholipid bilayer has been studied in different ways, and it seems the peptides penetrate the membrane through the formation of fibrillar protrusions [94]. The interaction of TL (and TB) with bacteria membrane has also been studied using spectroscopic techniques [95]. This peptide displays the highest antimicrobial potency among temporins tested to date and has strong affinity for lipid membranes and for the LPS component of the gram-negative outer membrane [72].

As stated earlier, LPS are important in temporin studies. The temporins not only interact with LPS but also can exhibit a synergistic effect when more than two temporins are combined $[96,97]$. As found for TA, TL also can be administrated intraperitoneally with piperacillin and imipenem, two $\beta$-lactam antibiotic agents, and play a strong synergistic activity against some E. coli strains [72].

In a study using more than 20 different bacteria strains, antimicrobial activity of TL and TB was analyzed. The TL showed at least 10-fold higher activity against all microorganisms tested than TB. In contrast with other temporins, which are known to be active against gram-positive bacteria, TL also displayed very good activity against gram-negative bacterial strains such as $E$. coli and $P$. aeruginosa. Results also showed an important cytotoxic activity to three different human tumor cell lines (Hut-78, K-562, and U-937). Another study of the interaction of TL with liposomes of different lipid compositions revealed that the peptide causes 
perturbation of bilayer integrity of both neutral and negatively charged membranes. These characteristics make TL a special AMP for many of the human pathogens [98].

Another work reported the mode of action of TL on E. coli D21 cells. The results showed that the peptide increased the permeability of the bacterial inner membrane in a dosedependent manner without destroying the integrity of the cell and preserving DNA integrity [99]. Also, together with TB, its mechanism of action into cell membrane has been studied in different ways, with the aim to understand its insertion into lipid monolayers as well as the effects on the structural dynamics of liposomal bilayers [100].

Finally, Saviello et al. [101] developed new analogues with potential biologic activities named Pro $^{3}$-TL and $\mathrm{Gln}^{3}$-TA, in which Pro $^{3}$ from TA was changed by a Gln, and the $\mathrm{Gln}^{3}$ from TL was changed by a Pro. They performed a detailed nuclear magnetic resonance analysis of the new analogues in sodium dodecyl sulfate (SDS) and dodecylphosphocholine micelles, which mimic bacterial and mammalian membranes, respectively. Their results showed that Pro $^{3}$-TL exhibited an increased antimicrobial activity toward gram-positive and yeast cells, with a hemolytic activity 2-5-fold lower than that of the natural TL, over a concentration range of 3-12 mcM. Gln ${ }^{3}$-TA also exhibited promising antimicrobial activity, but its hemolytic activity became significantly stronger compared with that of parent peptide TA (up to 10-fold higher).

Because the hemolytic activity of TL was associated with its strong propensity for helical structure at the N-terminus, authors replaced a proline residue in position 3 with the aim of inducing a turn structure in the derivative Pro ${ }^{3}$-TL. In the case of $\mathrm{Gln}^{3}$-TA, according to the authors, replacement of the native proline residue with a glutamine should lead to increased helical content at the N-terminus. Their results confirmed the existence of N-terminal turn structures in the Pro $^{3}$-TL and the existence of R-helix in N-terminus region of $\mathrm{Gln}^{3}$-TA. This confirms that helical content controls the hemolytic effect, while it is irrelevant to the antimicrobial activity of the temporins [101].

\section{Other Temporins}

Since the discovery of temporins by Simmaco et al. [10], several groups of researchers isolated different peptides from various species of frogs that were included as members of this family (Table 1). Both $S$. aureus and E. coli were chosen as model micro-organisms for the analysis of the antimicrobial activity against gram-positive and gram-negative bacteria, respectively. In addition, $C$. albicans was the main model organism for the analysis of the anti-micotic activity of these peptides. Table 2 resumes the antimicrobial activity of the temporins discovered until today.

Although antimicrobial activity of many temporins has not been analyzed yet, there are common properties between the peptides. For example, most of the temporins with tested antimicrobial activity have a +1 charge (Fig. 1), most temporins with antimicrobial activity against gram-negative bacteria already have activity against gram-positive bacteria, except for $1 \mathrm{PRb}$ from $R$. pirica [51] and the 1CS temporin family, from the skin of $R$. cascadae [29]. The two temporins without net charge (temporin $\mathrm{GH}$ and $1 \mathrm{Od}$ ) have no acidic or basic amino acids and are active against gram-positive bacteria $[36,48]$. Those temporins with +2 net charge are only active against gram-positive bacteria, except for temporin L, $\mathrm{CPa}$, and 1DRa, which are also active against gram-negative and fungi $[30,31,95,102]$.

Some of these temporins were chosen for different antimicrobial studies. For example, temporins SHa-c (TSHa-c) was assayed against bacteria, filamentous fungi, and yeasts. The results reported by Abbassi et al. [59] showed that SHa was active against most of the tested micro-organisms at micro-molar concentrations; SHc was inactive against gramnegative bacteria but effectively inhibited the proliferation of yeasts and fungi. On the other hand, temporin TSHb was virtually inactive against all the tested micro-organisms [59].

The TSHa was also selected to design hybrid silylated biomolecules based on TSHa amphipathic helical antimicrobial sequence and titanium surfaces for the attachment of the peptides. With the design of five TSHa analogs, Masurier et al. [103] showed that the antibacterial activity of the temporin-grafted surfaces was greater on the E. coli strain than on the $S$. epidermidis strain, regardless of the anchoring position. Wang et al. [22] isolated a temporin family (named AL) from the skin secretion of the Chinese frog Amolops loloensis with antimicrobial activity against gram-positive, gram-negative bacteria and fungus, as TSHa [22].

Urban et al. [102] chose two different temporins (temporin $1 \mathrm{DRa}$ from $R$. aurora draytonii and temporin-1Va from $R$. virgatipes) to analyze the growth inhibitory activity of synthetic replicates of these peptides against a range of reference strains and clinical isolates of gram-positive and gram-negative $[66,104]$. Temporin 1DRa was the only peptide to show inhibitory activity. It also showed relatively low hemolytic activity against human erythrocytes, which could represent a potential candidate for drug development, particularly for topical therapy of infected surface lesions [102].

Conlon et al. [104] analyzed the toxicity against mammalian cells of temporin 1DRa modified by different amino acid substitutions by replacing different amino acid residues by $\alpha$-aminoisobutyric acid (Aib). The Aib substitutions could induce a $\beta$-turn in small peptides but, in larger peptides, the residue could either promote the formation of an $\alpha$-helix or stabilize an existing helical conformation.

This study was focused not only on the effect of these substitutions but also on the effect of the modification of the dissolution buffer. Regarding the Leu ${ }^{9}$, Ile $^{13}$, Leu $^{14}$ substitutions, the peptide presented lower cytolytic activity against mammalian cells, retaining the antimicrobial activity over the microorganisms tested. Substitution of the Gly ${ }^{4}, \mathrm{Thr}^{5}, \mathrm{Asn}^{8}$, and Ala ${ }^{10}$ residues by Aib produced analogs that showed increased antimicrobial potencies against the gram-positive bacteria $S$. aureus (fourfold for $\mathrm{Aib}^{4}$ and $\mathrm{Aib}^{8}$, twofold for $\mathrm{Aib}^{5}$ and $\mathrm{Aib}^{10}$ ) and against $C$. albicans, but only the $\mathrm{Aib}^{8}$ analog showed increased potency (twofold) against the gram-negative bacteria E. coli $[104]$.

Twelve analogues of temporin 1DRa were also tested as alternatives to manage infections by multi-drug resistant pathogens in skin infection. Results showed that some of these peptides were promising candidates for further development into therapeutic agents for topical treatment of skin infections. Two other temporins (temporins HN1-2, THN1-2) were tested against 12 different species of micro-organisms. Both peptides proved to be effective against all the microorganisms tested $[39,105]$. 
Table 2. Antimicrobial and Hemolytic Activities of Temporins

\begin{tabular}{|c|c|c|c|c|c|c|}
\hline \multirow[b]{2}{*}{ Temporin } & \multirow[b]{2}{*}{ Amino acid sequence } & \multicolumn{3}{|c|}{ Antimicrobial activity } & \multirow{2}{*}{$\begin{array}{c}\text { Hemolytic } \\
\text { activity }\end{array}$} & \multirow[b]{2}{*}{ Reference } \\
\hline & & Gram + & Gram - & Fungi & & \\
\hline A & FLPLIGRVLSGIL-NH 2 & $2.3 \mathrm{mcM}$ & $11.9 \mathrm{mcM}$ & $3.4 \mathrm{mcM}$ & $>120 \mathrm{mcM}$ & [10] \\
\hline $\mathrm{B}$ & LLPIVGNLLKSLL-NH $_{2}$ & $6.0 \mathrm{mcM}$ & $21 \mathrm{mcM}$ & $4.0 \mathrm{mcM}$ & $>120 \mathrm{mcM}$ & [10] \\
\hline $\mathrm{L}$ & FVQWFSKFLGRIL-NH & $3.0 \mathrm{mcM}$ & $12.0 \mathrm{mcM}$ & $12.0 \mathrm{mcM}$ & $94 \mathrm{mcM}$ & [10] \\
\hline $1 \mathrm{ARa}$ & FLPIVGRLISGLL-NH ${ }_{2}$ & $15.0 \mathrm{mcM}$ & $125.0 \mathrm{mcM}$ & NA & NA & [19] \\
\hline $1 \mathrm{AUa}$ & PLPIIGQLLSGLL-NH & $>80 \mathrm{mcM}$ & ND & ND & NA & [20] \\
\hline ALa & FLPIVGKLLSGLSGLL-NH ${ }_{2}$ & $2.0 \mathrm{mcM}$ & $3.0 \mathrm{mcM}$ & $6.5 \mathrm{mcM}$ & ND & [21] \\
\hline ALd & FLPIAGKLLSGLSGLL-NH $_{2}$ & $>1 \mathrm{mcM}$ & $>1 \mathrm{mcM}$ & $>1 \mathrm{mcM}$ & $7.5 \mu \mathrm{M}$ & [22] \\
\hline ALe & FFPIVGKLLFGLSGLL-NH $_{2}$ & $>1 \mathrm{mcM}$ & $>1 \mathrm{mcM}$ & $>1 \mathrm{mcM}$ & $5.8 \mu \mathrm{M}$ & {$[22]$} \\
\hline ALf & FFPIVGKLLSGLSGLL-NH & $1.5 \mathrm{mcM}$ & $1.5 \mathrm{mcM}$ & $1.5 \mathrm{mcM}$ & $4.2 \mathrm{mcM}$ & {$[22]$} \\
\hline ALg & FFPIVGKLLFGLFGLL-NH & $1.4 \mathrm{mcM}$ & $2.8 \mathrm{mcM}$ & $>1 \mathrm{mcM}$ & $8.9 \mathrm{mcM}$ & [22] \\
\hline ALh & FLPIVGKLLSGLSGLS-NH & $1.6 \mathrm{mcM}$ & $3.1 \mathrm{mcM}$ & $1.6 \mathrm{mcM}$ & $8.1 \mathrm{mcM}$ & [22] \\
\hline ALi & FFPIVGKLLSGLL-NH ${ }_{2}$ & $5.3 \mathrm{mcM}$ & $5.3 \mathrm{mcM}$ & $3.5 \mathrm{mcM}$ & $15.0 \mathrm{mcM}$ & [22] \\
\hline $\mathrm{ALj}$ & FFPIVGKLLFGLL-NH & $5.1 \mathrm{mcM}$ & $10.2 \mathrm{mcM}$ & $3.4 \mathrm{mcM}$ & $13.0 \mathrm{mcM}$ & [22] \\
\hline $\mathrm{ALk}$ & FFPIVGKLLS-NH ${ }_{2}$ & $13.4 \mathrm{mcM}$ & $26.8 \mathrm{mcM}$ & $13.4 \mathrm{mcM}$ & $22.3 \mathrm{mcM}$ & [22] \\
\hline $1 \mathrm{BYa}$ & FLPIIAKVLSGLL-NH 2 & $15 \mathrm{mcM}$ & NA & NA & NA & [23] \\
\hline $1 \mathrm{Cb}$ & FLPLFASLIGKLL-NH $_{2}$ & $140 \mathrm{mcM}$ & NA & NA & NA & {$[24]$} \\
\hline $1 \mathrm{Cd}$ & FLPFLASLLSKVL-NH ${ }_{2}$ & $80 \mathrm{mcM}$ & NA & NA & NA & [24] \\
\hline $1 \mathrm{Ce}$ & FLPFLATLLSKVL-NH ${ }_{2}$ & $>100 \mathrm{mcM}$ & NA & NA & NA & [24] \\
\hline $1 \mathrm{CEa}$ & FVDLKKIANIINSIF-NH $_{2}$ & $14.4 \mathrm{mcM}$ & $>100 \mathrm{mcM}$ & ND & NA & [25] \\
\hline $1 \mathrm{CEb}$ & ILPILSLIGGLLGK-NH $_{2}$ & $41 \mathrm{mcM}$ & $>100 \mathrm{mcM}$ & ND & NA & [25] \\
\hline $\mathrm{CDYb}$ & ILPILAPLIGGLL-NH $_{2}$ & $>100 \mathrm{mcM}$ & $>100 \mathrm{mcM}$ & ND & $180 \mathrm{mcM}$ & [26] \\
\hline CG1 & FLPFVGNLLKGLL-NH ${ }_{2}$ & $9 \mathrm{mcM}$ & NA & NA & NA & {$[28]$} \\
\hline CG2 & FFPIVGKLLSGLF-NH ${ }_{2}$ & $150 \mathrm{mcM}$ & NA & NA & NA & [28] \\
\hline CG3 & FLPIVGKLLSGLF-NH 2 & $150 \mathrm{mcM}$ & NA & NA & NA & [28] \\
\hline CG4 & FLPILGNLLNGLL-NH & NA & NA & NA & NA & [28] \\
\hline CG5 & FLPFVGNLLNGLL-NH ${ }_{2}$ & NA & NA & NA & NA & [28] \\
\hline $1 \mathrm{CSa}$ & FLPIVGKLLSGLL-NH ${ }_{2}{ }^{-}$ & $8 \mathrm{mcM}$ & $128 \mathrm{mcM}$ & ND & $75 \mathrm{mcM}$ & [29] \\
\hline $1 \mathrm{CSb}$ & FLPIIGKLLSGLL-NH 2 & $8 \mathrm{mcM}$ & $128 \mathrm{mcM}$ & ND & $95 \mathrm{mcM}$ & [29] \\
\hline $1 \mathrm{CSc}$ & FLPLVTGLLSGLL-NH $_{2}$ & $64 \mathrm{mcM}$ & $>128 \mathrm{mcM}$ & ND & NA & [29] \\
\hline $1 \mathrm{CSd}$ & NFLGTLVNLAKKIL-NH $_{2}$ & $16 \mathrm{mcM}$ & $64 \mathrm{mcM}$ & ND & $50 \mathrm{mcM}$ & [29] \\
\hline $\mathrm{CPa}$ & IPPFIKKVLTTVF-NH ${ }_{2}$ & $2.3 \mathrm{mcM}$ & $2.3 \mathrm{mcM}$ & $+(<20 \mathrm{mcM})$ & NA & [30] \\
\hline $\mathrm{CPb}$ & FLPIVGRLISGIL-NH ${ }_{2}$ & ND & ND & ND & ND & [30] \\
\hline 1DRa & HFLGTLVNLAKKIL-NH & $5 \mathrm{mcM}$ & $20 \mathrm{mcM}$ & $40 \mathrm{mcM}$ & $70 \mathrm{mcM}$ & [31] \\
\hline $1 \mathrm{DRb}$ & NFLGTLVNLAKKIL-NH 2 & $20 \mathrm{mcM}$ & $40 \mathrm{mcM}$ & $80 \mathrm{mcM}$ & $65 \mathrm{mcM}$ & {$[31]$} \\
\hline 1DYa & FIGPIISALASLFG- $\mathrm{NH}_{2}$ & $>60 \mathrm{mcM}$ & $>60 \mathrm{mcM}$ & ND & ND & [32] \\
\hline $1 \mathrm{Ec}$ & FLPIIAGLLSKLF-NH ${ }_{2}$ & $8 \mathrm{mcM}$ & NA & ND & ND & [33] \\
\hline $1 \mathrm{Ee}$ & FLPVIAGVLSKLF-NH ${ }_{2}$ & $10 \mathrm{mcM}$ & $40 \mathrm{mcM}$ & NA & ND & [34] \\
\hline $1 \mathrm{~Gb}$ & SILPTIVSFLSKFL-NH ${ }_{2}$ & $24 \mathrm{mcM}$ & NA & NA & ND & [35] \\
\hline $1 \mathrm{Gc}$ & SILPTIVSFLTKFL-NH $_{2}$ & $25 \mathrm{mcM}$ & NA & NA & ND & [35] \\
\hline $1 \mathrm{Gd}$ & FILPLIASFLSKFL-NH $_{2}$ & $12 \mathrm{mcM}$ & NA & NA & ND & [35] \\
\hline $\mathrm{GH}$ & FLPLLFGAISHLL-NH $_{2}$ & $44.3 \mathrm{mcM}$ & NA & NA & ND & [36] \\
\hline HN1 & AILTTLANWARKFL-NH ${ }_{2}$ & $37.5 \mathrm{mcM}$ & NA & $75 \mathrm{mcM}$ & $75 \mathrm{mcM}$ & [39] \\
\hline $\mathrm{HN} 2$ & NILNTIINLAKKIL-NH ${ }_{2}$ & $4.8 \mathrm{mcM}$ & NA & $9.5 \mathrm{mcM}$ & NA & [39] \\
\hline $1 \mathrm{La}$ & VLPLISMALGKLL-NH ${ }_{2}$ & $60 \mathrm{mcM}$ & ND & ND & ND & [41] \\
\hline $1 \mathrm{Lb}$ & NFLGTLINLAKKIM-NH 2 & $48 \mathrm{mcM}$ & NA & NA & ND & [41] \\
\hline $1 \mathrm{Lc}$ & FLPILINLIHKGLL-NH 2 & $125 \mathrm{mcM}$ & NA & NA & ND & [41] \\
\hline LK1 & FFPLLFGALSSMMPKLF-NH & $1.3 \mathrm{mcM}$ & $15 \mathrm{mcM}$ & $2.6 \mathrm{mcM}$ & $51 \mathrm{mcM}$ & [42] \\
\hline LTa & FFPLVLGALGSILPKIF-NH ${ }_{2}$ & $11 \mathrm{mcM}$ & ND & NA & $5 \mathrm{mcM}$ & [43] \\
\hline $\mathrm{LTb}$ & FIITGLVRGLTKLF-NH 2 & $8 \mathrm{mcM}$ & ND & NA & $127 \mathrm{mcM}$ & [43] \\
\hline LTc & SLSRFLSFLKIVYPPAF-NH $\mathrm{N}_{2}$ & $25 \mathrm{mcM}$ & ND & NA & $100.8 \mathrm{mcM}$ & [43] \\
\hline LTe & FLAGLIGGLAKML-NH 2 & $9.5 \mathrm{mcM}$ & NA & NA & $40 \mathrm{mcM}$ & [44] \\
\hline LT1 & FLPGLIAGIAKML-NH ${ }_{2}$ & $9.3 \mathrm{mcM}$ & ND & NA & $74.5 \mathrm{mcM}$ & [45] \\
\hline LT2 & FLPIALKALGSIFPKIL-NH ${ }_{2}$ & $7 \mathrm{mcM}$ & ND & NA & $109 \mathrm{mcM}$ & [45] \\
\hline $1 \mathrm{Oa}$ & FLPLLASLFSRLL-NH ${ }_{2}$ & $2.0 \mathrm{mcM}$ & $70 \mathrm{mcM}$ & ND & ND & [47] \\
\hline $1 \mathrm{Ob}$ & FLPLIGKILGTIL-NH ${ }_{2}$ & $5 \mathrm{mcM}$ & $140 \mathrm{mcM}$ & NA & ND & [47] \\
\hline $1 \mathrm{Oc}$ & FLPLLASLFSRLF-NH $_{2}$ & $2 \mathrm{mcM}$ & NA & ND & ND & [47] \\
\hline $1 \mathrm{Od}$ & FLPLLASLFSGLF-NH 2 & $13 \mathrm{mcM}$ & NA & ND & ND & [47] \\
\hline $1 \mathrm{Oe}$ & ILPLLGNLLNGLL-NH ${ }_{2}$ & NA & NA & NA & ND & [48] \\
\hline $1 \mathrm{P}$ & FLPIVGKLLSGLL-NH & $110 \mathrm{mcM}$ & ND & ND & ND & [41] \\
\hline $1 \mathrm{PRa}$ & ILPILGNLLNGLL-NH $_{2}$ & $>100 \mathrm{mcM}$ & $>100 \mathrm{mcM}$ & $>100 \mathrm{mcM}$ & NA & [51] \\
\hline $1 \mathrm{PRb}$ & ILPILGNLLNSLL-NH $_{2}$ & $>100 \mathrm{mcM}$ & $>100 \mathrm{mcM}$ & $>100 \mathrm{mcM}$ & NA & {$[51]$} \\
\hline $\mathrm{PRa}$ & FLPILGNLLSGLL-NH & $50 \mathrm{mcM}$ & $>100 \mathrm{mcM}$ & ND & ND & [52] \\
\hline $\mathrm{PRb}$ & FLPIITNLLGKLL-NH ${ }_{2}$ & $6 \mathrm{mcM}$ & $>100 \mathrm{mcM}$ & ND & $35 \mathrm{mcM}$ & [52] \\
\hline
\end{tabular}


TABle 2. (CONTINUED)

\begin{tabular}{|c|c|c|c|c|c|c|}
\hline \multirow[b]{2}{*}{ Temporin } & \multirow[b]{2}{*}{ Amino acid sequence } & \multicolumn{3}{|c|}{ Antimicrobial activity } & \multirow{2}{*}{$\begin{array}{c}\text { Hemolytic } \\
\text { activity }\end{array}$} & \multirow[b]{2}{*}{ Reference } \\
\hline & & Gram + & Gram - & Fungi & & \\
\hline PRc & NFLDTLINLAKKFI-NH $_{2}$ & $50 \mathrm{mcM}$ & $>100 \mathrm{mcM}$ & $>50 \mathrm{mcM}$ & $80 \mathrm{mcM}$ & {$[52]$} \\
\hline $\mathrm{Ra}$ & FLKPLFNAALKLLP-NH 2 & $22.1 \mathrm{mcM}$ & $15.3 \mathrm{mcM}$ & ND & ND & [54] \\
\hline $\mathrm{Rb}$ & FLPVLAGVLSRA-NH ${ }_{2}$ & $28.4 \mathrm{mcM}$ & $27.8 \mathrm{mcM}$ & ND & ND & [54] \\
\hline $1 \mathrm{Re}$ & FLPGLLAGLL-NH ${ }_{2}$ & $60 \mathrm{mcM}$ & NA & NA & ND & [34] \\
\hline RN1 & FLPLVLGALSGILPKIL-NH ${ }_{2}$ & $2.7 \mathrm{mcM}$ & NA & $4.7 \mathrm{mcM}$ & ND & [55] \\
\hline RN3 & FFPLLFGALSSHLPKLF-NH & $3.9 \mathrm{mcM}$ & $7.8 \mathrm{mcM}$ & $1.9 \mathrm{mcM}$ & ND & {$[55]$} \\
\hline $1 \mathrm{Sa}$ & FLSGIVGMLGKLF-NH 2 & $3 \mathrm{mcM}$ & $10 \mathrm{mcM}$ & $16 \mathrm{mcM}$ & $25 \mu \mathrm{M}$ & [56] \\
\hline $1 \mathrm{Sb}$ & FLPIVTNLLSGLI-NH $_{2}$ & $58 \mathrm{mcM}$ & NA & $>116 \mathrm{mcM}$ & $>116 \mu \mathrm{M}$ & [56] \\
\hline $1 \mathrm{Sc}$ & FLSHIAGFLSNLF-NH 2 & $10 \mathrm{mcM}$ & $>80 \mathrm{mcM}$ & $20 \mathrm{mcM}$ & $>80 \mathrm{mcM}$ & [56] \\
\hline $1 \mathrm{SKa}$ & FLPVILPVIGKLLNGIL-NH ${ }_{2}$ & $25 \mathrm{mcM}$ & $>50 \mathrm{mcM}$ & $>50 \mathrm{mcM}$ & ND & {$[57]$} \\
\hline $1 \mathrm{SKb}$ & FLPVILPVIGKLLSGIL-NH ${ }_{2}$ & $25 \mathrm{mcM}$ & $>50 \mathrm{mcM}$ & ND & ND & [57] \\
\hline $1 \mathrm{SPb}$ & FLSAITSLLGKLL-NH ${ }_{2}$ & $6 \mathrm{mcM}$ & ND & ND & $60 \mathrm{mcM}$ & [58] \\
\hline SHa & FLSGIVGMLGKLF-NH 2 & $3 \mathrm{mcM}$ & $10 \mathrm{mcM}$ & $16 \mathrm{mcM}$ & $25 \mathrm{mcM}$ & [59] \\
\hline $\mathrm{SHb}$ & FLPIVTNLSGLL-NH 2 & $58 \mathrm{mcM}$ & $>116 \mathrm{mcM}$ & $>116 \mathrm{mcM}$ & $>116 \mathrm{mcM}$ & [59] \\
\hline SHc & FLSHIAGFLSNLF-NḦ & $10 \mathrm{mcM}$ & NA & $20 \mathrm{mcM}$ & $>80 \mathrm{mcM}$ & [59] \\
\hline SHd & FLPAALAGIGGILGKLF-NH ${ }_{2}$ & $6.5 \mathrm{mcM}$ & $>25 \mathrm{mcM}$ & $100 \mathrm{mcM}$ & $44 \mathrm{mcM}$ & [59] \\
\hline SHf & FFFLSRIF-NH ${ }_{2}$ & $12.5 \mathrm{mcM}$ & $>80 \mathrm{mcM}$ & $50 \mathrm{mcM}$ & $200 \mathrm{mcM}$ & [23] \\
\hline SN1 & FFPFLLGALGSLLPKIF-NH 2 & $12.5 \mathrm{mcM}$ & NA & NA & ND & [61] \\
\hline $\mathrm{SN} 2$ & FITGLIGGLMKAL-NH ${ }_{2}$ & $100 \mathrm{mcM}$ & NA & NA & ND & [61] \\
\hline SN3 & FISGLIGGLMKAL-NH ${ }_{2}$ & $25 \mathrm{mcM}$ & NA & NA & ND & [61] \\
\hline SN4 & FITGLISGLMKAL-NH ${ }_{2}$ & $12.5 \mathrm{mcM}$ & NA & NA & ND & [61] \\
\hline $1 \mathrm{Va}$ & FLSSIGKILGNLL-NH ${ }_{2}$ & $20 \mathrm{mcM}$ & $40 \mathrm{mcM}$ & NA & $120 \mathrm{mcM}$ & [66] \\
\hline $1 \mathrm{Vb}$ & FLSIIAKVLGSLF-NH & $10 \mathrm{mcM}$ & NA & NA & $30 \mathrm{mcM}$ & [66] \\
\hline $1 \mathrm{Vc}$ & FLPLVTMLLGKLF-NH $_{2}$ & $10 \mathrm{mcM}$ & NA & NA & $30 \mathrm{mcM}$ & [66] \\
\hline
\end{tabular}

The criteria were selected according to the bibliography: High (minimum inhibitory concentrations [MICs] $<5$ mcM); positive MICs $<50$ $\mathrm{mcM}$ ); low (MICs between $50 \mathrm{mcM}$ and $150 \mathrm{mcM}$ ); NA (not active up to $150 \mathrm{mcM}$ ); ND (no data). In all cases, the micro-organisms selected for the information were Staphylococcus aureus, Escherichia coli, and Candida albicans.

Temporin $\mathrm{CPa}$ from Lithobates capito has an atypical sequence IPPFIKKVLTTVF-NH $\mathrm{N}_{2}$, and unlike most of the temporins, it showed atypical growth-inhibitory activity having greater potency against $E$. coli and $C$. albicans than against $S$. aureus [30]. Yang et al. [28] found a group of peptides (temporins TC $1-5, \mathrm{TCG}_{1-5}$ ) with antimicrobial activity against gram-positive bacteria at low concentrations compared to other AMPs. Abbassi et al. [56] isolated three peptides, named temporins $1 \mathrm{Sa}-\mathrm{c}$ from the skin of the Sahara frog Pelophylax (Rana) saharica. As temporin 1G, $1 \mathrm{Sa}$ was effective against gram-positivebacteria [56].

Some temporins have low or no antimicrobial activity, although they present conserved features to the active peptides (13 amino acids, one basic amino acid, +1 charge). For example, temporins SPa-c showed very low antimicrobial activity, with positive response only for $S$. aureus [58]. Temporins 1PRa-b, Ska-b, and LT also showed low antimicrobial activity with gram-positive bacteria, very low or no activity with gram-negative bacteria, and no effectiveness against yeasts [35-37,41,43,51,57,62,105,106].

Finally, new temporins were found in different researches. The first, temporin Wa (TWa) was found in Lithobates warszewitschii, and it was not possible to establish the complete amino acid sequence (FISKIASLGAGVLX-NH Table 1). A second temporin found in the skin secretion of $R$. muscosa (1M) was isolated as free acid form. This was an unexpected finding because the presence of such peptides in frog skin secretions has not been reported previously. Authors determined that it is unclear whether the peptide is an authentic secretion product or is derived by artifactual hydrolysis during the extraction and purification process. Experiments with a pathogenic chytrid fungus showed that this temporin inhibited chytrids at concentrations above $6.25 \mathrm{mM}$ with a minimum inhibitory concentration (MIC) of $100 \mathrm{mM}$ against zoospores [46]. No other antimicrobial activity has been tested yet.

A third one, temporin LK1 (TLK1), was found in Limnonectes kuhlii frogs. This peptide of 17 amino acids showed antimicrobial activity against gram-positive and gram-negative bacteria and fungi [42]. This temporin was also selected for an antimicrobial activity analysis of five structural analogs. These peptides were prepared by substitution of achiral glycine residue of TLK1 with D-alanine, L-phenylglycine, and L-naphthylalanine, respectively. Analogs 2-4 showed activity against $P$. aeruginosa and $S$. aureus [106].

\section{Pharmacologic Application}

Antibiotic agents are essential in medicine for the control of pathogens in human and other species. Their abuse and misuse, however, have increased the number of resistant micro-organisms. This entails the need to develop new and better alternatives for multi-drug-resistant bacteria [107,108]. Peptides are molecules with a simple chemical structure that can be synthesized at low-cost on a large scale. In addition, it is feasible to chemically modify them to improve their bioavailability, pharmacokinetics, and pharmacodynamics, among other advantages. 
These properties make them good candidates for new drug developments, especially those with synergistic effect when more than one peptide is combined. This can be exemplified by the combinations of TA, TB, and TL in studies against $E$. coli strains. As a consequence of the antibiotic therapy of gram-negative bacterial infections, LPS or endotoxins can be released. The use of compounds capable of sequestering LPS has been suggested to avoid sepsis. These three temporins showed a synergistic effect on LPS sequester [109,110]. On the other hand, TL avoided the LPS-induced self-assembly of TA and TB. For this reason, it has been suggested that AMPs in combination with other drugs, could be good candidates for antibacterial or anti-endotoxin treatment, avoiding the generation of bacterial resistance to the therapy $[96,111,112]$. These temporins could be used as potential drugs and represent promising alternatives to supply antibiotic agents.

In addition, temporins $\mathrm{B}$ and $\mathrm{L}$ can penetrate lipid monolayers and generate molecular interaction with different liposomes, which could be an alternative through the encapsulation of these peptides for drug administration [100]. Temporin 1DRa also could represent a potential candidate for a drug, as was explained earlier [102,105,113].

Today, the new challenge is to load the peptides into polymeric drug delivery systems. Recently, Piotrowska et al. [81] developed new polymeric carriers to control the release of TA and other AMPs to improve the use of new therapeutic candidates for the management of local infections.

Antifungal resistance has become a challenge for new drug design. Currently there are only five therapeutic alternatives for the management of fungal infections (azoles, echinocandins, polyenes, allylamines, and pyrimidine analogs). Most antifungal agents show high toxicity and undesirable side effects that limit their use in medicine. Patients with immunodeficiencies are more likely to have fungal infections develop. The use of antifungal agents as prophylactic agents, however, has favored the emergence of drug resistances in species of Candida and Cryptococcus as well as other pathogenic fungi $[113,114]$.

In addition to the design strategies for the production of more efficient drugs against pathogens with antibiotic resistance, the use of nanotechnology has been proposed for the development of new administration systems that are expected to spread widely and rapidly. In this way, the reduction of toxicity and side effects of current dugs can be achieved [115]. Combination of nanotechnology and AMPs in different antimicrobial treatments could be a promising alternative for resistance pathogens. Therefore, drugs must be of low cost so that lower income groups can easily get a treatment with new novel drug molecules, which can help to fight against drug resistance [108].

\section{Conclusion}

Although temporins have been gaining importance in antimicrobial studies, many of them have not been fully analyzed yet. Most of these peptides have shown interesting and promising properties, together with the advantages explained in this article. This makes this family a potential alternative for pharmacology and biotechnology industries, for the research of new drugs with more effective administration methods and minor injuries.
Although recent researches with the most studied temporins (TA, TB, and TL) showed the potential of these small peptides, the temporin family is still an unexplored AMP group in pharmacology industries. Some recently discovered temporins do not present photosensitive amino acids (as cysteine or tryptophan), which is an advantage for drug delivery, because the molecular and chemical stability of the peptides allow an efficient and secure administration. Although TL showed good antimicrobial activity, it has lower stability than other temporins, because it presents a tryptophan in its sequence.

Initially, TL was the only temporin with anti-gram-negative activity, but today there are many other peptides with the same antimicrobial activities and are more stable. These studies demonstrate that, even with the advancement in scientific research on the composition and antimicrobial activity of temporins, further studies are necessary to wholly understand their components and mechanisms of action.

The need for new and more effective antibiotic and antifungal agents makes necessary the discovery and application of new drugs based on natural peptides such as AMPs.

\section{Future Prospectives}

The AMPs are the future drugs and the promising alternative in the pharmacologic industry. Combination of AMPs with nanotechnology could be the answer to all the resistant pathogens that produce thousands of mortal diseases per year, especially in poor and underdeveloped countries. New discoveries in AMPs activities and efficiency are necessary to incorporate more suitable alternatives in the field of medicines. Temporins are a promising candidate for the improvement of new drugs doe topical use and oral administration. This is the next step in the investigation of these peptides that are not deeply studied.

\section{Acknowledgment}

SMR, ABC, MC.C, SAC., and SLG are career researchers of the CONICET.

\section{Funding Information}

This study was funded by grants of the University of Buenos Aires (20020130100060BA) and Ministerio de Ciencia, Tecnología e Innovación Productiva de la República Argentina (PICT PICT-2014-1508).

\section{Author Disclosure Statement}

No competing financial interests exist.

\section{References}

1. Ageitos JM, Sánchez-Pérez A, Calo-Mata P, Villa TG. Antimicrobial peptides (AMPs): Ancient compounds that represent novel weapons in the fight against bacteria. Biochem Pharmacol 2017;133:117-138.

2. Wang G, Li X, Wang X. APD3: The antimicrobial peptide database as a tool for research and education. Nucleic Acids Res 2016;44:1087-1093.

3. Waghu FH, Barai RS, Gurung $\mathrm{P}$, Idicula-Thomas $\mathrm{S}$. CAMP R3: a database on sequences, structures and sig- 
natures of antimicrobial peptides. Nucleic Acids Res 2016;44:1094-1097.

4. Zhao X, Wu H, Lu H, et al. LAMP: A database linking antimicrobial peptides. PLoS One 2013;8:e665567.

5. Cardillo AB, Martínez Ceron MC, Romero SM, et al. Péptidos antimicrobianos de plantas. Rev Farm 2018;160: 28-46.

6. Conlon JM. Reflections on a systematic nomenclature for antimicrobial peptides from the skins of frogs of the family Ranidae. Peptides 2008;29:1815-1819.

7. Conlon JM, Kolodziejek J, Nowotny N. Antimicrobial peptides from the skins of North American frogs. Biochim Biophys Acta 2009;1788:1556-1563.

8. Conlon JM. Structural diversity and species distribution of host-defense peptides in frog skin secretions. Cell Mol Life Sci 2011;68:2303-2315.

9. Simmaco M, De Biase D, Severini C, et al. Purification and characterization of bioactive peptides from skin extracts of Rana esculenta. Biochim Biophys Acta 1990; 1033:318-323.

10. Simmaco M, Mignogna G, Canofeni S, et al. Temporins, antimicrobial peptides from the European red frog Rana temporaria. Eur J Biochem 1996;242:788-792.

11. Krishnakumari V, Nagaraj R. Antimicrobial and hemolytic activities of crabrolin, a 13-residue peptide from the venom of the European hornet, Vespa crabro, and its analogs. J Pept Res 1997;50:88-93.

12. Argiolas A, Pisano JJ. Isolation and characterization of two new peptides, mastoparan $\mathrm{C}$ and crabrolin, from the venom of the European hornet, Vespa crabro. J Biol Chem 1984;259:10106-10111.

13. das Neves RC, Mortari MR, Schwartz EF, et al. Antimicrobial and antibiofilm effects of peptides from venom of social wasp and scorpion on multidrug-resistant Acinetobacter baumannii. Toxins (Basel) 2019; www.mdpi .com/2072-6651/11/4/216.

14. Konno K, Kazuma K, Rangel M, et al. New mastoparan peptides in the venom of the solitary eumenine wasp Eumenes micado. Toxins (Basel) 2019; www.mdpi.com/ 2072-6651/11/3/155.

15. Konno K, Hisada M, Fontana R, et al. Anoplin, a novel antimicrobial peptide from the venom of the solitary wasp Anoplius samariensis. Biochim Biophys Acta 2001;1550: 70-80.

16. Xu X, Li J, Lu Q, et al. Two families of antimicrobial peptides from wasp (Vespa magnifica) venom. Toxicon 2006;47:249-253.

17. Wade D, Silveira A, Silberring J, Kuusela P, et al. Temporin antibiotics peptides: A review and derivation of a consensus sequence. Protein Pept Lett 2000;7:349-357.

18. Rinaldi AC, Conlon JM. Temporins. In: Kastin AJ (ed): Anphibian/Skin Peptides, 2nd ed. London: Elsevier. Handbook of Biologically Active Peptides, 2013, pps 400-406.

19. Ali MF, Lips KR, Knoop FC, et al. Antimicrobial peptides and protease inhibitors in the skin secretions of the crawfish frog, Rana areolata. Biochim Biophys Acta 2002;1601:55-63.

20. Conlon JM, Sonnevend A, Davidson C, et al. Hostdefense peptides isolated from the skin secretions of the Northern red-legged frog Rana aurora aurora. Dev Comp Immunol 2005;29:83-90.

21. Lu Y, Li J, Yu H, et al. Two families of antimicrobial peptides with multiple functions from skin of rufous- spotted torrent frog, Amolops loloensis. Peptides 2006;27: 3085-3091.

22. Wang M, Wang Y, Wang A, et al. Five novel antimicrobial peptides from skin secretions of the frog, Amolops loloensis. Comp Biochem Physiol B Biochem Mol Biol 2010;155:72-76.

23. Conlon JM, Sonnevend A, Patel M, et al. Isolation of peptides of the brevinin-1 family with potent candidacidal activity from the skin secretions of the frog Rana boylii. J Pept Res 2003;62:207-213.

24. Halverson T, Basir YJ, Knoop FC, Conlon JM. Purification and characterization of antimicrobial peptides from the skin of the North American green frog Rana clamitans. Peptides 2000;21:469-4676.

25. Shang D, Yu F, Li J, et al. Molecular cloning of cDNAs encoding antimicrobial peptide precursors from the skin of the Chinese brown frog, Rana chensinensis. Zoolog Sci 2009;26:220-226.

26. Jin LL, Li Q, Song SS, et al. Characterization of antimicrobial peptides isolated from the skin of the Chinese frog, Rana dybowskii. Comp Biochem Physiol B Biochem Mol Biol 2009;154:174-178.

27. (a) CAMPD. Collection of Antimicrobial Peptides Database (2019a). www.camp.bicnirrh.res.in/seqDisp.php?id= CAMPSQ4462. (b) CAMPD. Collection of Antimicrobial Peptides Database (2019b). www.camp.bicnirrh.res.in/ seqDisp.php?id=CAMPSQ4463.

28. Yang X, Xia J, Yu Z, et al. Characterization of diverse antimicrobial peptides in skin secretions of Chungan torrent frog Amolops chunganensis. Peptides 2012;38:41-53.

29. Conlon JM, Al-Dhaheri A, Al-Mutawa E, et al. Peptide defenses of the Cascades frog Rana cascadae: Implications for the evolutionary history of frogs of the Amerana species group. Peptides 2007;28:1268-1274.

30. Conlon JM, Meetani MA, Coquet L, et al. Antimicrobial peptides from the skin secretions of the New World frogs Lithobates capito and Lithobates warszewitschii (Ranidae). Peptides 2009;30:1775-1781.

31. Conlon JM, Al-Ghafari N, Coquet L, et al. Evidence from peptidomic analysis of skin secretions that the red-legged frogs, Rana aurora draytonii and Rana aurora aurora, are distinct species. Peptides 2006;27:1305-1312.

32. Conlon JM, Kolodziejek J, Nowotny N, et al. Cytolytic peptides belonging to the brevinin-1 and brevinin-2 families isolated from the skin of the Japanese brown frog, Rana dybowskii. Toxicon 2007;50:746-756.

33. Ali MF, Knoop FC, Vaudry H, Conlon JM. Characterization of novel antimicrobial peptides from the skins of frogs of the Rana esculenta complex. Peptides 2003;24: 955-961.

34. Chen X, Wang H, Yang M, et al. Identification and bioactivity evaluation of two novel temporins from the skin secretion of the European edible frog, Pelophylax kl esculentus. Biochem Biophys Res Commun 2016;476:566573.

35. Kim JB, Halverson T, Basir YJ, et al. Purification and characterization of antimicrobial and vasorelaxant peptides from skin extracts and skin secretions of the North American pig frog Rana grylio. Regul Pept 2000;90:5360.

36. Zhou J, McClean S, Thompson A, et al. Purification and characterization of novel antimicrobial peptides from the skin secretion of Hylarana guentheri. Peptides 2006;27: 3077-3084. 
37. Conlon JM, Power GJ, Abdel-Wahab YH, et al. A potent, non-toxic insulin-releasing peptide isolated from an extract of the skin of the Asian frog, Hylarana guntheri (Anura: Ranidae). Regul Pept 2008;151:153-159.

38. Conlon JM, Coquet L, Leprince J, et al. Peptidomic analysis of skin secretions from Rana heckscheri and Rana okaloosae provides insight into phylogenetic relationships among frogs of the Aquarana species group. Regul Pept 2007;138:87-93.

39. Wang H, Yu Z, Hu Y, et al. Novel antimicrobial peptides isolated from the skin secretions of Hainan odorous frog, Odorrana hainanensis. Peptides 2012;35:285-290.

40. Isaacson $\mathrm{T}$, Soto A, Iwamuro $\mathrm{S}$, et al. Antimicrobial peptides with atypical structural features from the skin of the Japanese brown frog Rana japonica. Peptides 2002; 23:419-425.

41. Goraya J, Wang Y, Li Z, et al. Peptides with antimicrobial activity from four different families isolated from the skins of the North American frogs Rana luteiventris, Rana berlandieri and Rana pipiens. Eur J Biochem 2000;267: 894-900.

42. Wang G, Wang Y, Ma D, et al. Five novel antimicrobial peptides from the Kuhl's wart frog skin secretions, Limnonectes kuhlii. Mol Biol Rep 2013;40:1097-1102.

43. Wang H, Lu Y, Zhang X, et al. The novel antimicrobial peptides from skin of Chinese broad-folded frog, Hylarana latouchii (Anura: Ranidae). Peptides 2009;30:273282.

44. Wang $\mathrm{H}, \mathrm{Yu} \mathrm{Z}, \mathrm{Hu} \mathrm{Y}$, et al. Molecular cloning and characterization of antimicrobial peptides from skin of the broad-folded frog, Hylarana latouchii. Biochimie 2012; 94:1317-1326.

45. Wang $\mathrm{H}$, Yan $\mathrm{X}, \mathrm{Yu} \mathrm{H}$, et al. Isolation, characterization and molecular cloning of new antimicrobial peptides belonging to the brevinin-1 and temporin families from the skin of Hylarana latouchii (Anura: Ranidae). Biochimie 2009;91:540-547.

46. Rollins-Smith LA, Woodhams DC, Reinert LK, et al. Antimicrobial peptide defenses of the mountain yellowlegged frog (Rana muscosa). Dev Comp Immunol 2006; 30:831-842.

47. Kim JB, Iwamuro S, Knoop FC, Conlon JM. Antimicrobial peptides from the skin of the Japanese mountain brown frog, Rana ornativentris. J Pept Res 2001;58: 349-356.

48. Ohnuma A, Conlon JM, Yamaguchi K, et al. Antimicrobial peptides from the skin of the Japanese mountain brown frog Rana ornativentris: Evidence for polymorphism among preprotemporin mRNAs. Peptides 2007;28: 524-532.

49. Conlon JM, Coquet L, Leprince J, et al. Peptidomic analysis of skin secretions from Rana heckscheri and Rana okaloosae provides insight into phylogenetic relationships among frogs of the Aquarana species group. Regul Pept 2007; 138:87-93.

50. Zhou M, Wang L, Owens DE, et al. Rapid identification of precursor cDNAs encoding five structural classes of antimicrobial peptides from pickerel frog (Rana palustris) skin secretion by single step "shotgun" cloning. Peptides 2007;28:1605-1610.

51. Conlon JM, Sonnevend A, Patel M, et al. A family of brevinin-2 peptides with potent activity against Pseudomonas aeruginosa from the skin of the Hokkaido frog, Rana pirica. Regul Pept 2004;118:135-141.
52. Conlon JM, Mechkarska M, Ahmed E, et al. Host defense peptides in skin secretions of the Oregon spotted frog Rana pretiosa: Implications for species resistance to chytridiomycosis. Dev Comp Immunol 2011;35:644-649.

53. Conlon JM, Kolodziejek J, Nowotny N, et al. Characterization of antimicrobial peptides from the skin secretions of the Malaysian frogs, Odorrana hosii and Hylarana picturata (Anura: Ranidae). Toxicon 2008;52:465-473.

54. Asoodeh A, Zardini HZ, Chamani J. Identification and characterization of two novel antimicrobial peptides, temporin-Ra and temporin-Rb, from skin secretions of the marsh frog (Rana ridibunda). J Pept Sci 2012;18:10-16.

55. Ma Y, Liu C, Liu X, et al. Peptidomics and genomics analysis of novel antimicrobial peptides from the frog, Rana nigrovittata. Genomics 2010;95:66-71.

56. Abbassi F, Oury B, Blasco T, et al. Isolation, characterization and molecular cloning of new temporins from the skin of the North African ranid Pelophylax saharica. Peptides 2008;29:1526-1533.

57. Suzuki H, Iwamuro S, Ohnuma A, et al. Expression of genes encoding antimicrobial and bradykinin-related peptides in skin of the stream brown frog Rana sakuraii. Peptides 2007; 28:505-514.

58. Bevier CR, Sonnevend A, Kolodziejek J, et al. Purification and characterization of antimicrobial peptides from the skin secretions of the mink frog (Rana septentrionalis). Comp Biochem Physiol C Toxicol Pharmacol 2004;139: 31-38.

59. Abbassi F, Galanth C, Amiche M, , et al. Solution structure and model membrane interactions of temporins-SH, antimicrobial peptides from amphibian skin. A NMR spectroscopy and differential scanning calorimetry study. Biochemistry 2008;47:10513-10525.

60. Abbassi F, Raja Z, Oury B, et al. Antibacterial and leishmanicidal activities of temporin-SHd, a 17-residue long membrane-damaging peptide. Biochimie 2013;95: 388-399.

61. Yang X, Hu Y, Xu S, et al. Identification of multiple antimicrobial peptides from the skin of fine-spined frog, Hylarana spinulosa (Ranidae). Biochimie 2013;95:24292436.

62. Conlon JM, Sonnevend A, Patel M, et al. A melittinrelated peptide from the skin of the Japanese frog, Rana tagoi, with antimicrobial and cytolytic properties. Biochem Biophys Res Commun 2003;306:496-500.

63. Iwamuro S, Nakamura M, Ohnuma A, Conlon JM. Molecular cloning and sequence analyses of preprotemporin mRNAs containing premature stop codons from extradermal tissues of Rana tagoi. Peptides 2006;27:21242128.

64. Conlon JM, Al-Ghaferi N, Abraham B, et al. Antimicrobial peptides from the skin of the Tsushima brown frog Rana tsushimensis. Comp Biochem Physiol C Toxicol Pharmacol 2006;143:42-49.

65. Chen T, Zhou M, Rao P, et al. The Chinese bamboo leaf odorous frog (Rana (Odorrana) versabilis) and North American Rana frogs share the same families of skin antimicrobial peptides. Peptides 2006;27:1738-1744.

66. Conlon JM, Abraham B, Sonnevend A, et al. Purification and characterization of antimicrobial peptides from the skin secretions of the carpenter frog Rana virgatipes (Ranidae, Aquarana). Regul Pept 2005;131:38-45.

67. Mangoni ML, Rinaldi AC, Di Giulio A, et al. Structurefunction relationships of temporins, small antimicrobial 
peptides from amphibian skin. Eur J Biochem 2000;267: 1447-1454.

68. Wade D, Silberring J, Soliymani R, et al. Antibacterial activities of temporin A analogs. FEBS Lett 2000;479: 6-9.

69. D’Abramo M, Rinaldi AC, Bozzi A, et al. Conformational behavior of temporin $\mathrm{A}$ and temporin $\mathrm{L}$ in aqueous solution: A computational/experimental study. Biopolymers 2006;81:215-224.

70. Manzo G, Ferguson PM, Gustilo BV, et al. Minor sequence modifications in temporin B cause drastic changes in antibacterial potency and selectivity by fundamentally altering membrane activity. Sci Rep 2019;9:1385.

71. Abbassi F, Lequin O, Piesse C, et al. Temporin-SHf, a new type of phe-rich and hydrophobic ultrashort antimicrobial peptide. J Biol Chem 2010;285:16880-16892.

72. Giacometti A, Cirioni O, Ghiselli R, et al. Interaction of antimicrobial peptide temporin $\mathrm{L}$ with lipopolysaccharide in vitro and in experimental rat models of septic shock caused by gram-negative bacteria. Antimicrob Agents Chemother 2006;50:2478-2486.

73. Rollins-Smith LA, Carey C, Conlon JM, et al. Activities of temporin family peptides against the chytrid fungus (Batrachochytrium dendrobatidis) associated with global amphibian declines. Antimicrob Agents Chemother 2003; 47:1157-1160.

74. Harjunpää I1, Kuusela P, Smoluch MT, et al. Comparison of synthesis and antibacterial activity of temporin A. FEBS Lett. 1999;449:187-190.

75. Giacometti A, Cirioni O, Kamysz W, et al. In vitro activity and killing effect of temporin A on nosocomial isolates of Enterococcus faecalis and interactions with clinically used antibiotics. J Antimicrob Chemother. 2005; 55:272-274.

76. Wade D, Silveira A, Rollins-Smith L, et al. Hematological and antifungal properties of temporin A and a cecropin Atemporin A hybrid. Acta Biochim Pol 2001;48:11851189.

77. Hujakka H, Ratilainen J, Korjamo T, et al. Synthesis and antimicrobial activity of the symmetric dimeric form of temporin A based on 3-N,N-di(3-aminopropyl)amino propanoic acid as the branching unit. Bioorg Med Chem 2001;9:1601-1607.

78. Chen Q, Wade D, Kurosaka K, et al. Temporin A and related frog antimicrobial peptides use formyl peptide receptor-like 1 as a receptor to chemoattract phagocytes. J Immunol 2004;173:2652-2659.

79. Mangoni ML, Saugar JM, Dellisanti M, et al. Temporins, small antimicrobial peptides with leishmanicidal activity. J Biol Chem 2005;280:984-990.

80. Simonetti O, Cirioni O, Goteri G, et al. Temporin A is effective in MRSA-infected wounds through bactericidal activity and acceleration of wound repair in a murine model. Peptides 2008;29:520-528.

81. Piotrowska U, Oledzka E, Zgadzaj A, et al. A novel delivery system for the controlled release of antimicrobial peptides: Citropin 1.1 and temporin A. Polymers (Basel) 2018;10:489.

82. Musale V, Casciaro B, Mangoni ML, et al. Assessment of the potential of temporin peptides from the frog Rana temporaria (Ranidae) as anti-diabetic agents. J Pept Sci 2018;24:1-12.

83. Malgieri G, Avitabile C, Palmieri M, et al. Structural basis of a temporin $1 \mathrm{~b}$ analogue antimicrobial activity against
Gram negative bacteria determined by $\mathrm{CD}$ and NMR techniques in cellular environment. ACS Chem Biol 2015; 10:965-969.

84. Marcocci ME, Amatore D, Villa S, et al. The amphibian antimicrobial peptide temporin $\mathrm{B}$ inhibits in vitro herpes simplex virus 1 infection. Antimicrob Agents Chemother 2018;62:e02367-17.

85. Oh H, Hedberg M, Wade D, Edlund C. Activities of synthetic hybrid peptides against anaerobic bacteria: Aspects of methodology and stability. Antimicrob Agents Chemother 2000;44:68-72.

86. Avitabile C, Netti F, Orefice G, et al. Design, structural and functional characterization of a temporin- $1 \mathrm{~b}$ analog active against Gram-negative bacteria. Biochim Biophys Acta 2013; 1830:3767-3775.

87. Bezzerri V, Avitabile C, Dechecchi MC, et al. Antibacterial and anti-inflammatory activity of a temporin $\mathrm{B}$ peptide analogue on an in vitro model of cystic fibrosis. J Pept Sci 2014;20:822-830.

88. Di Grazia A, Luca V, Segev-Zarko LA, et al. Temporins $\mathrm{A}$ and $\mathrm{B}$ stimulate migration of HaCaT keratinocytes and kill intracellular Staphylococcus aureus. Antimicrob Agents Chemother 2014;58:2520-2527.

89. Maisetta G, Grassi L, Di Luca M, et al. Anti-biofilm properties of the antimicrobial peptide temporin $1 \mathrm{~Tb}$ and its ability, in combination with EDTA, to eradicate Staphylococcus epidermidis biofilms on silicone catheters. Biofouling 2016;32:787-800.

90. Rinaldi AC, Di Giulio A, Liberi M, et al. Effects of temporins on molecular dynamics and membrane permeabilization in lipid vesicles. J Pept Res 2001;58:213220.

91. Kang SJ, Park SJ, Mishig-Ochir T, Lee BJ. Antimicrobial peptides: Therapeutic potentials. Expert Rev Anti Infect Ther 2014;12:1477-1486.

92. Brogden NK, Brogden KA. Will new generation of modified antimicrobial peptides improve their potential as pharmaceuticals? Int J Antimicrob Agents 2011;38: 217-225.

93. Piras AM, Maisetta G, Sandreschi S, et al. Chitosan nanoparticles loaded with the antimicrobial peptide temporin B exert a long-term antibacterial activity in vitro against clinical isolates of Staphylococcus epidermidis. Front Microbiol 2015;6:372.

94. Domanov YA, Kinnunen PK. Antimicrobial peptides temporins $\mathrm{B}$ and $\mathrm{L}$ induce formation of tubular lipid protrusions from supported phospholipid bilayers. Biophys J 2006;91:4427-4439.

95. Carotenuto A, Malfi S, Saviello MR, et al. A different molecular mechanism underlying antimicrobial and hemolytic actions of temporins A and L. J Med Chem 2008; 51:2354-2362.

96. Mangoni ML, Epand RF, Rosenfeld Y, et al. Lipopolysaccharide, a key molecule involved in the synergism between temporins in inhibiting bacterial growth and in endotoxin neutralization. J Biol Chem 2008;283:2290722917.

97. Zhao H, Kinnunen PK. Binding of the antimicrobial peptide temporin L to liposomes assessed by Trp fluorescence. J Biol Chem 2002;277:25170-25177.

98. Rinaldi AC, Mangoni ML, Rufo A, et al. Temporin L: Antimicrobial, haemolytic and cytotoxic activities, and effects on membrane permeabilization in lipid vesicles. Biochem J 2002;368:91-100. 
99. Mangoni ML, Papo N, Barra D, et al. Effects of the antimicrobial peptide temporin $\mathrm{L}$ on cell morphology, membrane permeability and viability of Escherichia coli. Biochem J 2004;380:859-865.

100. Zhao H, Rinaldi AC, Di Giulio A, et al. Interactions of the antimicrobial peptides temporins with model biomembranes. Comparison of temporins B and L. Biochemistry 2002;41:4425-4436.

101. Saviello MR, Malfi S, Campiglia P, et al. New insight into the mechanism of action of the temporin antimicrobial peptides. Biochemistry 2010;49:1477-1485.

102. Urbán E, Nagy E, Pál T, et al. Activities of four frog skin-derived antimicrobial peptides (temporin-1DRa, temporin-1 $\mathrm{Va}$ and the melittin-related peptides AR-23 and $\mathrm{RV}-23$ ) against anaerobic bacteria. Int $\mathrm{J}$ Antimicrob Agents 2007;29:317-321.

103. Masurier N, Tissot JB, Boukhriss D, et al. Site-specific grafting on titanium surfaces with hybrid temporin antibacterial peptides. J Mater Chem B 2018;6:1782-1790.

104. Conlon JM, Al-Kharrge R, Ahmed E, et al. Effect of aminoisobutyric acid (Aib) substitutions on the antimicrobial and cytolytic activities of the frog skin peptide, temporin-1DRa. Peptides 2007;28:2075-2080.

105. Gaiser RA, Ayerra Mangado J, Mechkarska M, et al. Selection of antimicrobial frog peptides and temporin1DRa analogs for treatment of bacterial infections based on their cytotoxicity and differential activity against pathogens. Chem Biol Drug Des 2019. Epub ahead of print.

106. Shah ZA, Farooq S, Ali SA, et al. New analogs of temporin-LK1 as inhibitors of multidrug-resistant (MDR) bacterial pathogens. Synth Commun 2018;48:1172-1182.

107. Ko SJ, Kang NH, Kim MK, et al. Antibacterial and antibiofilm activity, and mechanism of action of pleurocidin against drug resistant Staphylococcus aureus. Microb Pathog 2019;127:70-78.
108. Upadhyay RK. Emerging concepts in medicinal chemistry for development of high potency drugs and diagnostics. Open Access Journal of Oncology 2019; chembiopublishers .com/OAJOY/OAJOY180007.pdf.

109. Scott MG, Vreugdenhil AC, Buurman WA, et al. Cutting edge: Cationic antimicrobial peptides block the binding of lipopolysaccharide (LPS) to LPS binding protein. J Immunol 2000;164:549-553.

110. Jerala R, Porro M. Endotoxin neutralizing peptides. Curr Top Med Chem 2004;4:1173-1184.

111. Mangoni ML, Shai Y. Temporins and their synergism against Gram-negative bacteria and in lipopolysaccharide detoxification. Biochim Biophys Acta 2009;1788:1610-1619.

112. Lewis D. Antimicrobial resistance surveillance: Methods will depend on objectives. J Antimicrob Chemother 2002; 49:3-5.

113. Geddes-McAlister J, Shapiro RS. New pathogens, new tricks: Emerging, drug-resistant fungal pathogens and future prospects for antifungal therapeutics. Ann N Y Acad Sci 2019;1435:57-78.

114. Campoy S, Adrio JL. Antifungals. Biochem Pharmacol 2017;133:86-96.

115. De Jong WH, Borm PJ. Drug delivery and nanoparticles: Applications and hazards. Int J Nanomedicine 2008;3: 133-149.

Address correspondence to: Dr. Silvana Laura Giudicessi Universidad de Buenos Aires

Facultad de Farmacia y Bioquímica Cátedra de Biotecnología Junín 956

1113 Buenos Aires Argentina

E-mail: silvanagiudicessi@gmail.com 